\title{
Maintenance of Cell Wall Integrity under High Salinity
}

\author{
Jianwei Liu ${ }^{1}$, Wei Zhang ${ }^{1,2}$, Shujie Long ${ }^{1,2}$ and Chunzhao Zhao ${ }^{1, *(1)}$ \\ 1 Shanghai Center for Plant Stress Biology, CAS Center for Excellence in Molecular Plant Sciences, \\ Chinese Academy of Sciences, Shanghai 200032, China; jwliu@psc.ac.cn (J.L.); weizhang@psc.ac.cn (W.Z.); \\ shjlong@psc.ac.cn (S.L.) \\ 2 University of the Chinese Academy of Sciences, Beijing 100049, China \\ * Correspondence: czzhao@psc.ac.cn; Tel.: +86-021-5707-8274
}

Citation: Liu, J.; Zhang, W.; Long, S.; Zhao, C. Maintenance of Cell Wall Integrity under High Salinity. Int. J. Mol. Sci. 2021, 22, 3260. https:// doi.org/10.3390/ijms22063260

Academic Editor: Raffaella Maria Balestrini

Received: 27 February 2021

Accepted: 19 March 2021

Published: 23 March 2021

Publisher's Note: MDPI stays neutral with regard to jurisdictional claims in published maps and institutional affiliations.

Copyright: (c) 2021 by the authors. Licensee MDPI, Basel, Switzerland. This article is an open access article distributed under the terms and conditions of the Creative Commons Attribution (CC BY) license (https:/ / creativecommons.org/licenses/by/ $4.0 /)$.

\begin{abstract}
Cell wall biosynthesis is a complex biological process in plants. In the rapidly growing cells or in the plants that encounter a variety of environmental stresses, the compositions and the structure of cell wall can be dynamically changed. To constantly monitor cell wall status, plants have evolved cell wall integrity (CWI) maintenance system, which allows rapid cell growth and improved adaptation of plants to adverse environmental conditions without the perturbation of cell wall organization. Salt stress is one of the abiotic stresses that can severely disrupt CWI, and studies have shown that the ability of plants to sense and maintain CWI is important for salt tolerance. In this review, we highlight the roles of CWI in salt tolerance and the mechanisms underlying the maintenance of CWI under salt stress. The unsolved questions regarding the association between the CWI and salt tolerance are discussed.
\end{abstract}

Keywords: cell wall integrity; cell wall sensor; salt stress; salt tolerance; LRXs; CrRLK1Ls

\section{Introduction}

High salinity is an adverse environmental stress that severely affects the growth and yield of crops. Excessive accumulation of sodium in plants confers both ion toxicity and osmotic stress, which in turn dramatically affect the morphological, physiological, biochemical, and metabolic status of plants [1]. Currently, more than $20 \%$ of the irrigated lands in the world are threatened by high salinity, and the area of saline soils is increasing gradually every year accompanied by the global climate change and poor irrigation practices [2-4]. It is expected the global population will reach to nearly 10 billion in 2050, and to meet the increasing food demand in future, the utilization of saline soils to grow major crops tends to be inevitable. Therefore, the cultivation of crops with increased salt tolerance is a major objective in salt stress community.

To avoid the damage caused by excessive salts in soil, plants have evolved various strategies to overcome the problems caused by high salinity. Ion homeostasis, osmotic adjustment, ROS balance, and metabolic adjustment are the major factors that are associated with the tolerance of plants to salt stress. Based on the capacity of plants to adapt to salt stress, plants can be classified into glycophytes and halophytes. Our major crops, such as rice, maize, and wheat, are glycophytes that are unable to complete their life cycle when they are being exposed to high salinity. Halophytes, however, have developed various strategies to adapt to the environments with a high concentration of sodium. For example, halophytes are able to extrude salts via glands or store excessive $\mathrm{Na}^{+}$in the vacuoles of epidermal bladder cells $[5,6]$.

More and more studies point out that maintenance CWI is also critical for the adaptation of plants to high salinity. Plant cell walls, which mainly consist of polysaccharides and structural proteins, are essential for the establishment of plant morphology and protection of plants against adverse environmental changes [7]. During plant growth and development or in response to environmental stresses, the cell wall compositions and structures are 
dynamically modulated, allowing rapid cell elongation and increased stress tolerance [8]. To maintain CWI during the reorganization of cell wall, plants need to constantly monitor the chemical and mechanical properties of the cell walls and also need to process an ability to repair cell wall once they are seriously disrupted. It has been shown that CWI maintenance mechanism exists in plants and is essential for the regulation of growth and development and in response to stress conditions $[9,10]$. The progresses about CWI sensing and maintenance system in plants have been summarized in several outstanding review papers $[8,11,12]$. In this review, we focus on the elucidation of the associations between CWI and salt tolerance in plants.

\section{Importance of Cell Wall Biosynthesis in Salt Tolerance}

The plant cell wall is a dynamic network composed of cellulose, hemicellulose, pectin, lignin, and multiple types of structural proteins [13,14]. Moreover, cell wall-remodeling enzymes, various ions, and reactive oxygen species (ROS) also exist in the apoplast and are involved in the regulation of CWI. Upon exposure to high salinity, several changes in the cell wall have been identified, including the reduction of cellulose content [15,16], disruption of the cross-linking of pectins [9], and accumulation of lignin [17]. Studies have shown that the plants that are defective in cell wall biosynthesis are hypersensitive to salt stress, suggesting that maintenance of CWI is important for the adaptation of plants to high salinity.

\subsection{Cellulose}

Cellulose is the most abundant organic component in the cell wall of terrestrial vascular plants. Cellulose micro-fibrils are composed of $\beta-1,4-$ linked glucan chains, which are synthesized at the cell surface by cellulose synthase (CesA) complexes (CSCs) $[18,19]$. Each CSC is assembled into a hexameric rosette structure, harboring CesA catalytic subunits and several accessory proteins. In Arabidopsis, there are ten CesA proteins [18]. It is well known that CesA1, CesA3, and CesA6 are assembled in a CSC to synthesize cellulose in the primary cell wall, while CesA4, CesA7, and CesA8 are mainly involved in the synthesis of cellulose in the secondary cell wall [20]. Experimental data have shown that the cellulose contents are significantly reduced after salt treatment and the plants with a loss of function of CESA1 and CESA6 gene display reduced root elongation and severe root tip swelling under salt stress, indicating that cellulose biosynthesis is important for salt tolerance in plants [21,22]. Clear evidences have indicated that the CSCs are dissociated from plasma membrane within $30 \mathrm{~min}$ after exposure to high salinity. However, during the growth recovery phase after salt treatment, the CSCs can be reassembled at the plasma membrane to synthesize new cellulose, and the capacity to reassemble CSCs during the growth recovery stage is critical for plants to maintain root and hypocotyl growth under salt stress [16].

Apart from the CesAs, several cellulose biosynthesis-related proteins have also been reported involved in salt tolerance. For example, KORRIGAN1 (KOR1), a putative endo$1,4-\beta$-D-glucanase, is an integral part of the primary cell wall CSC and is required for root elongation under salt stress [22,23]. Cellulose synthase interacting protein 1 (CSI1) and companion of cellulose synthase 1 (CC1 and CC2) proteins, acting as companions of CesAs, are both required for cellulose biosynthesis [16,21]. Mutations in CSI1 or CC1 and CC2 lead to reduced root or hypocotyl elongation under salt stress. CTL1 encodes a chitinase-like protein that participates in the deposition of the ordered cellulose, and mutation of this gene results in increased sensitivity to high salinity [24] (Table 1). 
Table 1. List of the cell wall biosynthesis-related genes that are involved in salt stress response.

\begin{tabular}{|c|c|c|c|c|}
\hline Name & Gene ID & Annotation & Function & Reference(s) \\
\hline AtCesA1/RSW1 & At4g32410 & \multirow{2}{*}{ Cellulose synthase catalytic subunit } & Cellulose synthesis in the primary cell wall & [22] \\
\hline AtCesA8/IRX1 & At4g18780 & & Cellulose synthesis in the secondary cell wall & [25] \\
\hline $\begin{array}{l}\text { AtCC1 } \\
\text { AtCC2 }\end{array}$ & $\begin{array}{l}\text { At1g } 45688 \\
\text { At5o42860 }\end{array}$ & Cellulose synthase companion protein & Cortical microtubules assembly and cellulose biosynthesis under salt stress & [16] \\
\hline AtCTL/POM1 & At1g05850 & Chitinase-like protein 1 & Involved in the assembly of glucan chains & {$[24,26]$} \\
\hline AtCSI1/POM2 & At2g22125 & Cellulose synthase-interactive protein 1 & Companion of CesAs; required for cell elongation in root & [21] \\
\hline AtCCoAOMT1 & At4g34050 & Caffeoyl-CoA 3-O-methyltransferase & Involved in lignin synthesis & [17] \\
\hline AtKOR/RSW2 & At5g49720 & Endo- $\beta$-1,4-glucanase & Integral component of CSC; required for cell elongation in root & [23] \\
\hline AtGALS1 & At2g33570 & $\beta$-1,4-galactan synthase & $\begin{array}{l}\text { Arabinose biosynthesis; related to the modification of polysaccharides and glycoproteins } \\
\text { Transfer of galactose from UDP- } \alpha \text {-d-Gal or arabinopyranose from UDP- } \beta \text {-1-Ara } p \text { to } \\
\text { growing } \beta-1,4 \text {-galactan chains }\end{array}$ & {$[28,29]$} \\
\hline AtXTH30 & At1g32170 & $\begin{array}{l}\text { Xyloglucan endotrans } \\
\text { glucosylase-hydrolase }\end{array}$ & $\begin{array}{c}\text { Cleave or rejoin the xyloglucan; } x \text { th } 30 \text { mutation decreases crystalline cellulose content } \\
\text { and affects the depolymerization of microtubules under salt stress }\end{array}$ & [30] \\
\hline AtPMEI13 & At5g62360 & Pectin methyl-esterase inhibitor 13 & Inhibits the activity of PMEs & [31] \\
\hline $\begin{array}{l}\text { AtBPC1 } \\
\text { AtBPC2 }\end{array}$ & $\begin{array}{l}\text { At2g01930 } \\
\text { At1g14685 }\end{array}$ & BPC-type transcription factor & Regulation of the expression of AtGALS1 & [28] \\
\hline AtGCN5 & At3g54610 & Histone acetyltransferase & Epigenetic regulation of cell wall-related genes & [32] \\
\hline OsTSD2 & Os02g51860 & Pectin methyltransferase & Regulation of pectin metabolism & [33] \\
\hline
\end{tabular}




\subsection{Hemicellulose}

Hemicelluloses are grouped into xyloglucans (XyG), xylans, mannans, and $\beta-(1,3 ; 1,4)$ glucans, and the abundance and structure of these polysaccharides vary greatly in different plants species [35]. Xylan is considered as a cross-linking polysaccharide in the establishment of cell wall architecture $[35,36]$. XyG contributes to the strengthening of cell wall during cell elongation by binding to cellulose micro-fibrils with hydrogen bonds $[37,38]$. $\mathrm{XyG}$ can be cleaved by the cell wall remodeling enzymes xyloglucan endotransglucosylase/hydrolases (XTHs) [39]. After cleavage, the reducing end of the XyG is attached to the non-reducing end of another $\mathrm{XyG}$ oligomer or polymer to produce chimeric $\mathrm{XyG}$ molecules [39]. The XTHs-mediated modification of XyG is considered to be important for controlling cell wall extensibility. Studies have reported that XTHs are involved in salt stress response in plants. Arabidopsis XTH30, encoding a xyloglucan endotransglucosylase/hydrolase 30, is strongly upregulated under salt stress [30]. Loss of function of the XTH30 gene leads to increased salt tolerance, which is mainly caused by the slower reduction of crystalline cellulose content and alleviated depolymerization of microtubules in response to salt stress [30]. This result suggests that XTH30 plays a negative role in salt tolerance. However, the positive roles of XTHs in salt tolerance have also been reported. Constitutive expression of CaXTH3 in hot pepper [40,41] and PeXTH in Populus euphratica [42] enhance tolerance to salt stress, and disruption of XTH19 and XHT23 genes in Arabidopsis results in decreased salt tolerance [43].

\subsection{Pectin}

Pectin is a group of acidic polysaccharides that are enriched with $\alpha-(1,4)$-linked galacturonic acids in the backbone [44]. Pectin accounts for up to $40 \%$ of the dry weight of higher plant cell walls [44] and plays critical roles in plant growth and development [45], leaf senescence [46], biotic [47] and abiotic stress responses [48]. Pectin is composed of three major types: homogalacturonan (HG), rhamnogalacturonan-I (RG-I), and rhamnogalacturonan-II (RG-II) [7,44]. HG is synthesized in the Golgi apparatus and secreted to the apoplast in a highly methy-esterified form and later it is selectively de-esterified by pectin methyl esterases (PMEs) during cell growth and in response to environmental stimuli $[7,44]$. The degree and pattern of the methyl-esterification of pectin in some extent determines the stiffness of cell walls [49]. In Arabidopsis, there are around 66 members of PME family protein, and for most of PMEs, their activities can be inhibited by endogenous PME inhibitors (PMEIs) or a natural inhibitor epigallocatechin gallate (EGCG) [50,51]. High salinity triggers the demethyl-esterification of loosely bound pectins to inhibit cell swelling [52] and previous studies showed that the activity of PMEs is either positively or negatively associated with salt tolerance in plants [53]. For instance, null Arabidopsis function mutant pme13 is hypersensitive to $\mathrm{Na}^{+}$toxicity in seed germination and seedling growth [53]. In contrast, overexpression of Chorispora bungeana PMEI1 or AtPMEI13 in Arabidopsis causes decreased PMEs activity and enhanced methyl-esterification level of pectins, which subsequently improves seeds germination and survival rate under salt stress [31]. The de-esterified HG molecules can be cross-linked to form the so called egg-box structure, the process of which is mediated by divalent cations, such as $\mathrm{Ca}^{2+}$, and the formation of egg-box structure promotes cell wall stiffening [54]. In the presence of high concentration of $\mathrm{Na}^{+}$, the ratio of $\mathrm{Na}^{+} / \mathrm{Ca}^{2+}$ in the apoplast is increased, and $\mathrm{Na}^{+}$is supposed to replace $\mathrm{Ca}^{2+}$ to bind pectins and thus disturbs the cross-linking of pectins, leading to reduced cell elongation [55]. Besides, the borate-mediated cross-linking of RG-II contributes to the strength of cell wall and is required for the regulation of growth recovery after exposure to high salinity $[56,57]$.

The roles of pectin in salt tolerance have also been reported in rice. Polygalacturonase 1 (PG1) is a cell wall hydrolase that is responsible for the degradation of cell wall pectin. Overexpression of OsBURP16, which encodes a non-catalytic $\beta$ subunit of PG1, results in an increased pectin degradation and increased salt-hypersensitivity in rice [34]. OsTSD2 encodes a pectin methyltransferase in rice, and mutation in OsTSD2 leads to a higher content of $\mathrm{Na}^{+}$and a lower level of $\mathrm{K}^{+}$in rice shoot under high salinity, which is mainly 
caused by the reduced expression of genes that are responsible for the maintenance of ion homeostasis, such as OsHKT1;5, OsSOS1, and OsKAT1 [33] (Table 1).

\subsection{Lignin}

As one of the most abundant organic compound in plants, lignin is composed of phenylalanine-derived [58] or tyrosine-derived [59] aromatic monomer substances and is important for the secondary cell wall formation and the responses to a variety of environmental stresses [60]. High salinity induces the accumulation of lignin content and cell wall thickening via the activation of lignin biosynthesis pathway [60]. The accumulation of lignin contributes to the mechanical strengthening of cell wall and protection of membrane integrity under salt stress [61]. The effects of lignin accumulation on salt tolerance have been reported in different crops, including soybean [62], wheat [63], and tomato [64]. CCoAOMT encodes a caffeoyl CoA O-methyltransferase (CCoAOMT), which catalyzes caffeoyl CoA to feruloyl CoA in lignin biosynthesis pathway. The expression of CCOAOMT is induced in salt-adapted cell, and the plants with a loss-of-function of CCoAOMT are hypersensitive to salt stress [17]. BpMYB46 and BpNAC012, encoding two transcription factors in white birch (Betula platyphylla), are required for the up-regulation of lignin biosynthetic genes and salt stress-responsive genes, and overexpression of these two genes enhances salt tolerance in B. platyphylla $[65,66]$. AgNAC1, a nuclear-localized protein in celery, acts as a positive regulator in inducing the expression of lignin-related and salt stress-responsive genes, and overexpression of $A g N A C 1$ enhances the formation of secondary walls and plant salt tolerance [67].

\section{The Roles of the Cell Wall-Localized Glycoproteins in Salt Stress Response}

In addition to dynamic and complex polysaccharide networks, several types of cell wall proteins (CWPs) have been identified in the apoplast. CWPs play critical roles in cell wall modifications and cell wall stress signals transduction. Hydroxyproline (Hyp)-rich glycoproteins (HRGPs), proline-rich proteins (PRPs), glycine-rich proteins (GRPs), and arabinogalactan proteins AGPs are the major types of CWPs [68]. For most of CWPs, they are secreted into the apoplast in a glycosylation-modified form [69-71].

Extensins (EXTs) are a group of cell wall glycoproteins that belong to the HRGPs family. EXTs are typically characterized for the enrichment of Ser-(Hyp) ${ }_{3-5}$ repeats in their protein sequences [72], and each Hyp residue is decorated with up to five arabinose units by several different arabinosyltransferases, including HPAT1-HPAT3 [73], RRA1-RRA3 [74], XEG113 [75], and ExAD [76]. The arabinosylation of EXTs is suggested to be important for the fulfillment of their biological functions. Our recent study showed that the mutation of MUR4, which encodes an UDP-Xyl 4-epimerase that is essential for the conversion of UDPXyl to UDP-Ara $p$ in Golgi, results in reduced root elongation under salt stress, suggesting that arabinose biosynthesis and subsequently the modification of polysaccharides and glycoproteins by arabinose are important for salt tolerance in plants [27].

Leucine-rich repeat extensins (LRXs) are chimeric proteins that contain an $\mathrm{N}$-terminal leucine-rich repeat (LRR) domain that binds with interacting partners and a C-terminal extensin domain that is likely linked with the EXT network or polysaccharides in the apoplast [77]. LRXs gene family consists of 11 members in Arabidopsis, among of which $L R X 3, L R X 4$, and $L R X 5$ are dominantly expressed in vegetative tissues [77]. The biological functions of these three LRX proteins are redundant, as mutation of each single gene does not cause any obvious phenotypes, but $l r x 34$ double and $l r x 345$ triple mutants both exhibit dwarfism, increased accumulation of anthocyanin, and increased sensitivity to high salinity [10]. It is worth noting that all these phenotypes are more severe in the lrx345 triple mutant than that in the lrx34 double mutant. Our study indicated that fer-4 mutant as well as the transgenic plants overexpressing RALF22 and RALF23 exhibit similar phenotypes as $l r x 345$ in terms of plant growth and salt sensitivity, and biochemical data show that RALF22 and RALF23 are physically associated with LRX3/4/5 [10]. Combining the data showing that FER is the receptor of RALFs [9], we can conclude that the LRX3/4/5, the 
secreted peptide RALFs, and the receptor-like kinase FER function as a module to mediate salt stress response in the apoplast. It is supposed that the extensin domain of LRXs is able to anchor polysaccharides in the cell wall $[77,78]$, but it is still unknown whether LRXs directly participate in the sensing of CWI or coordinate with FER to perceive CWI (Figure 1).

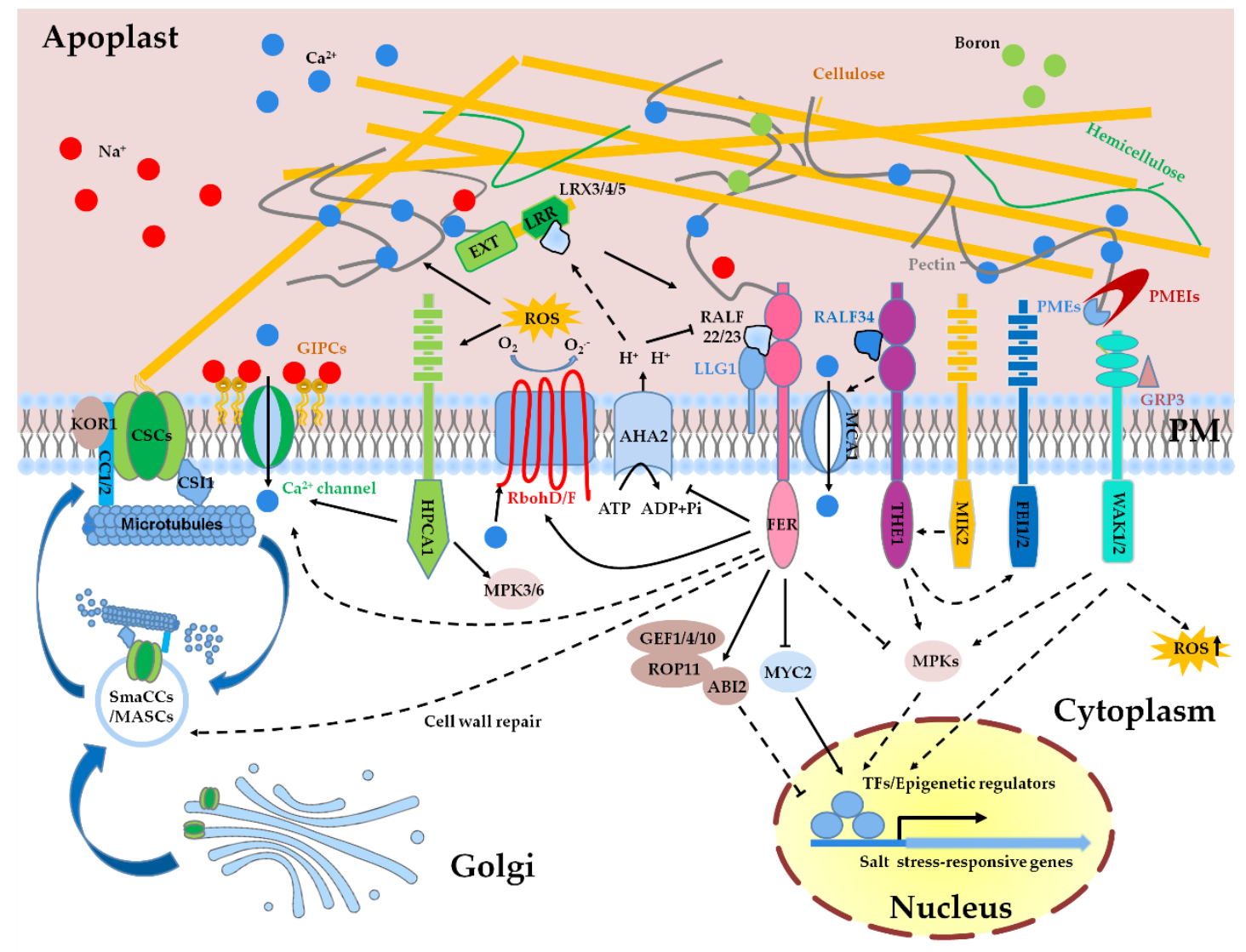

Figure 1. Sensing and maintenance of cell wall integrity under salt stress. Salt stress-induced cell wall changes are proposed to be sensed by multiple receptor-like kinases, including FER, THE1, MIK2, FEI1/2, and WAK1/2. As one of the most important cell wall integrity (CWI) sensors, FER may function alone or together with LRX3/4/5-RALF22/23 module to perceive the perturbation of CWI caused by high salinity. The AHA2-mediated acidification of the apoplastic pH increases the affinity of LRXs with RALFs, while the alkaline state in the apoplast promotes the binding of RALFs with FER. FER and probably also other cell wall sensors convert salt-triggered cell wall signals to multiple intracellular signals, including Ca ${ }^{2+}$, ROS, abscisic acid (ABA), jasmonic acid (JA), and MPKs, which in turn regulate the expression of salt stress-responsive genes in the nucleus. Salt stress can alter the redox status in the apoplast, and RbohD/F-mediated production of the apoplastic $\mathrm{H}_{2} \mathrm{O}_{2}$ may affect the cross-linking of cell wall polymers and activate $\mathrm{H}_{2} \mathrm{O}_{2}$ sensor HPCA1. Glycosyl inositol phosphorylceramide (GIPC) sphingolipids participate in the sensing of extracellular salt by directly binding to sodium ions. Cell wall biosynthesis- and modification-related components, including pectin methyl esterases (PMEs), PME inhibitors (PMEIs), and cellulose synthase (CesA), are involved in the regulation of salt tolerance in plants. Upon initial exposure to salt stress, cortical microtubules are depolymerized and cellulose synthase complex (CSC) together with its companions CSI1 and CC1/2 are internalized into small CesA compartments/microtubule-associated CesA compartments (smaCCs/MASCs). At the growth recovery stage after salt application, FER is probably required for the regulation of the reassembly of cortical microtubules and the relocation of CSCs to the plasma membrane to synthesize cellulose, which subsequently enhances the adaptation of plants to salt stress. Solid lines represent direct regulations, and dashed lines represent in-direct or potential regulations.

AGPs are highly glycosylated with arabinogalactan chains and are proposed to play important roles in salt stress response [69]. Our study showed that the reduced root elongation of the mur4 mutant under high salinity is partially caused by the decreased AGPs, 
as application of gum arabic, a commercial source of Acacia senegal AGPs, restores the root elongation of the mur4 mutant under salt stress [27]. As a glycosylphosphatidylinositol (GPI)-anchored fasciclin-like AGP, salt overly sensitive 5 (SOS5)/fasciclin-like arabinogalactan-protein 4 (FLA4) was identified based on a screening of mutants with increased sensitivity to salt stress. The sos5/fla 4 mutant exhibits reduced root elongation and severe root tip swelling under salt stress $[79,80]$. SOS5 is glycosylated by galactosyltransferase 2 (GALT2) and GALT5, both of which belong to AGP-specific galactosyltransferases. The galt 2 galt 5 double mutant displays a similar phenotype as the sos5/fla4 mutant in the presence of high concentration of $\mathrm{NaCl}$ [80]. Recently, studies showed that AGPs are able to cross-link with cell wall components. For instance, arabinoxylan pectin arabinogalactan protein 1 (APAP1) is covalently linked to pectins [81], and arabinogalactan protein 31 (AGP31) physically associates with methyl-esterified polygalacturonic acid and galactans, which are the branches of RG-I [82].

Expansins, first isolated from growing cucumber hypocotyls, consist of four subfamilies: $\alpha$-expansin, $\beta$-expansin, expansin-like A, and expansin-like B [83,84]. Expansins are key regulators of cell-wall loosening and are required for cell enlargement under a variety of environmental stresses [85]. Several studies have shown that the expression of expansin-encoding genes is induced by high salt and the elevation of the protein levels of expansins tends to promote salt tolerance in plants. ZmEXPB2, ZmEXPB6, and ZmEXPB8 genes in maize [86], AsEXP1 gene in turf grass [87], and OsEXPA3 gene in rice [88], are induced upon exposure to high salinity. Down-regulation of ZmEXPB6 is correlated with the reduced leaf growth of maize under salt stress [89]. Overexpression of rice expansin 7 (OsEXPA7) confers substantially enhanced tolerance to salt stress by lowering reactive oxygen species (ROS) accumulation and increasing antioxidant activity in rice [90]. Ectopic expression of wheat expansin 2 (TaEXPA2) or TaEXPB23 improves salt tolerance in tobacco $[91,92]$. Although expansins have been known to positively regulate salt stress response in multiple species, few studies have revealed the mechanisms underlying the expansins-mediated regulation of salt tolerance.

\section{Salt Stress Alters the Redox Status in the Apoplast}

Reactive oxygen species (ROS) are a class of metabolites, including hydrogen peroxide, singlet oxygen, superoxide, and hydroxyl radicals, which are produced in chloroplasts, mitochondria, peroxisomes, and apoplast [93]. The salt stress-triggered production of ROS and their effects on CWI have been widely reported in plants [93-95]. ROS triggers the cross-linking of cell wall compounds and enhances the mechanical strength of cell wall under a short-term stress exposure. Under a prolonged stress treatment, the formation of hydroxyl radicals $(\bullet \mathrm{OH})$ cleave plant polysaccharides, leading to cell wall loosening [96]. The ROS-induced lignin biosynthesis facilitates the adaptation of plants to high salt environment $[95,97]$.

The production of ROS in the apoplast is mainly mediated by respiratory burst oxidase homolog D (RbohD) and RbohF [98], two NADPH oxidases that are localized at the plasma membrane. NADPH oxidases transfer electrons from cytosolic NADPH or NADH to apoplastic oxygen, leading to the production of superoxide $\left(\mathrm{O}_{2}{ }^{-}\right)$, which is then catalyzed to hydrogen peroxide $\left(\mathrm{H}_{2} \mathrm{O}_{2}\right)$ by superoxide dismutases [99]. The expression of $\mathrm{RbohD}$ and $R b o h F$ is induced under salt stress and rbohD rbohF double mutant is hypersensitive to salt stress [100], suggesting that the ROS production in the apoplast is required for salt tolerance. Salt-induced production of ROS by RbohD/F is able to activate $\mathrm{Ca}^{2+}$ channel to increase the influx of $\mathrm{Ca}^{2+}$ into cytosol, which mediates the modulation of $\mathrm{Na}^{+} / \mathrm{K}^{+}$homeostasis [100]. The $\mathrm{H}_{2} \mathrm{O}_{2}$ generated by RbohD/F during the early stage of stress treatment also acts as a signal molecule to activate antioxidant system to attenuate salt stress-induced oxidative damages [101]. Recent studies showed that RbohD/F form nanoclusters at the plasma membrane in response to osmotic stress and later they are internalized into the cytoplasm via membrane microdomains [102-104]. As high salt conditions are accompanied by 
osmotic stress, the formation of $\mathrm{RbohD} / \mathrm{F}$ as nanoclusters at the plasma membrane is perhaps also the case in the plants being exposed to high salinity (Figure 1).

Class III peroxidases are heme-containing enzymes, which are mainly localized in the apoplast and vacuole. Class III peroxidases either positively or negatively modulate apoplastic ROS levels [105]. Class III peroxidases explore $\mathrm{H}_{2} \mathrm{O}_{2}$ and $\mathrm{O}_{2}{ }^{-}$to generate $\bullet \mathrm{OH}$, which leads to the cleavage of polysaccharides and promotes cell wall loosening [106]. Class III peroxidase 71 (PRX71), which is strongly up-regulated in response to cell wall damage (CWD), negatively regulates growth and cell size and positively regulates ROS accumulation [94]. GsPRX9, encoding a Class III peroxidase, is induced by salt treatment in soybean root, and the soybean transgenic plants overexpressing GsPRX9 exhibit increased root growth and decreased $\mathrm{H}_{2} \mathrm{O}_{2}$ content under salt stress [107].

The biological significance of the salt stress-induced redox change in the apoplast is still far from being fully understood. One of the outputs of the redox change is to affect the formation of intra- and inter-molecular disulfide bond. A large number of cell wall-localized glycoproteins and secreted peptides are characterized with the enrichment of cysteines, which are potentially involved in the formation of disulfide bonds. Therefore, we can speculate that the salt stress-induced redox change can affect the intra- and inter-molecular disulfide bridges of cell wall glycoproteins, which in turn transduce cell wall signals to the cellular interior. LRX8 and RALF4, which are both required for the regulation of pollen tube growth, process cysteines that are involved in the formation of disulfide bridges. A recent structural study showed that the formation of LRX8 homodimer and also the physical association of RALF4 with LRX8 require oxidative environment. Abolishment of the disulfide bonds via sites mutation or treatment of proteins with dithiothreitol (DTT) largely prevents the formation of LRX8 homodimer and affects the affinity of LRX8 with RALF4 [108]. These results suggest that the redox status in the cell wall is required for the regulation of the formation of LRXs-RALFs complex. Based on this hypothesis, we propose that the salt stress-induced change of apoplastic redox status may affect the formation of homo- and hetero-dimers of LRX3/4/5 and also affect the affinity of LRX3 $/ 4 / 5$ proteins with RALFs, which finally transduce salt stress signals to the intracellular signaling pathways.

\section{The Impact of Apoplastic $\mathbf{p H}$ on Salt Tolerance}

In the early 1970s, the acid growth theory was proposed, which states that acidification of the apoplast promotes cell elongation, whereas alkaline state in the apoplast prevents cell growth [109]. The reduction of apoplastic $\mathrm{pH}(\mathrm{apo} \mathrm{pH})$ activates several cell wall proteins, including expansins and other remodeling enzymes, resulting in the loosening of cell wall [110]. apo $\mathrm{pH}$ in linear growing cells is regulated by plasma membrane-localized $\mathrm{H}^{+}$-ATPases (AHAs) [111]. RALFs are a class of peptides that cause the alkalinization of the apoplast by regulating $\mathrm{H}^{+}$-ATPases via Catharanthus roseus RLK1-like kinases (CrRLK1Ls). FER is one of the CrRLK1L family proteins that consist of two carbohydrate-binding malectin-like domains, a transmembrane domain, and an intracellular serine/threoninekinase domain [112,113]. FER inhibits the proton transport activity of AHA2 likely via direct phosphorylation [114]. It is known that salinity triggers the transient alkalization in the apoplast and inhibits plant growth [115], and our study showed that salt stress can induce the formation of mature RALFs [10]. These data suggest that salt stress-induced alkalinization of the apoplast is probably mediated by RALFs-FER-AHA2 module and the acidification of the extracellular environment is important for salt tolerance. Two halophyte species, Atriplex lentiformis and Chenopodium quinoa, which have a capacity to tolerate a high concentration of sodium ion, display a high $\mathrm{H}^{+}$-ATPase activity under salt stress, which contributes to a low apopH and fast $\mathrm{Na}^{+}$efflux [116]. SOS1, encoding a plasma membrane membrane-localized $\mathrm{Na}^{+} / \mathrm{H}^{+}$antiporter, is required for the extrusion of excessive $\mathrm{Na}^{+}$ from the cytosol [117]. The $\mathrm{Na}^{+} / \mathrm{H}^{+}$exchange activity of SOS1 is absent under normal growth conditions. Upon salt stress, however, $\mathrm{Na}^{+}$-induces induced formation of an ATP-dependent $\mathrm{pH}$ gradient can enhance the $\mathrm{Na}^{+} / \mathrm{H}^{+}$transport activity of SOS1 [118]. 
Altogether, low apopH facilitates plant growth under salt stress, but the direct effects of low apopH on cell wall networks need more detailed studies.

\section{Cell Wall Integrity Sensing and Signal Transduction under High Salinity}

Unlike the traditional activation of plant receptor-like kinases by the corresponding ligands, the sensing of CWI is not limited by ligand-receptor pattern, e.g., recognition of wall fragments released from the damaged cell walls by receptor-like kinases, and is probably also achieved via the recognition of the cell wall modifications and the alteration of redox and apopH status. Currently, a series of plasma membrane-localized receptor-like kinases and cell wall glycoproteins have been identified that are involved in the sensing and maintenance of CWI. As a universal signal molecule, $\mathrm{Ca}^{2+}$ is also involved in the transduction of CWI signaling signals in plants.

The cell wall appears to be the largest source of $\mathrm{Ca}^{2+}$ in plant cell [119]. Under normal conditions, $\mathrm{Ca}^{2+}$ is used to stabilize pectins via the dimerization of HG chains [120]. AGPs have been shown to bind abundant $\mathrm{Ca}^{2+}$ [121]. Under salt stress, the excessive accumulation of $\mathrm{Na}^{+}$in the apoplast disrupts ion homeostasis, leading to rapid sodiumspecific calcium waves occurred in roots [122]. The imported calcium ions directly bind the EF hands of RbohD/F and improve their catalytic activity $[123,124] . \mathrm{Ca}^{2+}$ is also an initial signal to activate the SOS signaling pathway, which promotes the extrusion of $\mathrm{Na}^{+}$from the cytosol $[125,126]$.

In addition to high salinity, other abiotic stresses, such as drought, cold, and osmotic stress, can also induce the cytosolic $\mathrm{Ca}^{2+}$ influx within a few seconds to minutes. Although the induction of $\mathrm{Ca}^{2+}$ signaling is a common event for these different abiotic stresses, studies have shown that the different stresses-triggered $\mathrm{Ca}^{2+}$ influx is mediated by different components. Reduced hyperosmolality-induced $\left[\mathrm{Ca}^{2+}\right]_{i}$ increase 1 (OSCA1) is specifically required for the osmotic stress-triggered uptake of $\mathrm{Ca}^{2+}$ [127], and hydrogen-peroxideinduced $\mathrm{Ca}^{2+}$ increases 1 (HPCA1) is required for $\mathrm{H}_{2} \mathrm{O}_{2}$-, but not for salt- and osmotic stress, induced influx of $\mathrm{Ca}^{2+}$ [128]. Glycosyl inositol phosphorylceramide (GIPC) sphingolipids, which are glycosylated via glucuronosyltransferase MOCA1, was discovered as a sensor of extracellular salt by directly binding to sodium ions [129]. The moca1 mutant lacking functional GIPCs is defective in the activation of $\mathrm{Ca}^{2+}$ waves when being exposed to high concentration of $\mathrm{Na}^{+}, \mathrm{K}^{+}$, or $\mathrm{Li}^{+}$ion. GIPCs can bind $\mathrm{Na}^{+}$to gate $\mathrm{Ca}^{2+}$ influx channels and trigger the activation of SOS signaling pathway. However, which $\mathrm{Ca}^{2+}$ channels are activated by GIPCs and the mechanism underlying the activation need further study (Figure 1).

FER is considered as a CWI sensor and required for the activation of $\mathrm{Ca}^{2+}$ influx and maintenance of CWI under salt stress [9]. Mutation of FER reduces salt-induced $\mathrm{Ca}^{2+}$ influx in the root epidermis and increases sensitivity to high salinity. FER contains two malectin domains that have been experimentally demonstrated to directly bind with de-methylesterified HG in vitro and in vivo $[9,130]$, suggesting that FER probably senses the cell wall changes directly via its extracellular domain and then transduces the cell wall signals to cellular interior via its cytoplasmic kinase domain. However, how the modification of pectin affects the activity of FER is still elusive. Our recent study showed that LRX3/4/5, RALFs, and FER function as a module to regulate salt stress response, which implies that FER-mediated perception of CWI probably needs the aid of LRX3/4/5-RALFs regulatory module [10]. Salt stress may dissociate the LRX3/4/5-RALFs complex via the salt stressinduced redox and $\mathrm{pH}$ changes in the apoplast, and the released RALFs bind to LLG1-FER complex and thereby allow the transduction of cell wall signals. The mechanism behind the dissociation of LRX3/4/5 and RALFs under salt stress needs to be further investigated.

THESEUS1 (THE1) is a CrRLK1L family protein that was first identified in a screening for the suppressors of prc1-1 [131]. The null mutation of the1 partially suppresses the stunted growth and lignin deposition of the prc1-1 mutant, despite the reduced cellulose content in the prc1-1 is not restored [131]. HERKULES1 (HERK1) is another CrRLK1L protein that is phylogenetically closely related to FER and THE1. Double mutant herk1 
the1-4 displays similar phenotypes as fer-4 in terms of growth and salt stress response [52]. A recent study indicates that THE1 acts as the receptor of RALF34 to fine-tune lateral root initiation [132]. These results suggest that FER, THE, and HERK1 may work together to replay RALFs-mediated cell wall signals, but the biochemical associations among these three CrRLK1L proteins are still largely unknown.

Male discoverer 1-interacting receptor like kinase 2 (MIK2) is a leucine-rich repeat receptor-like kinase (LRR-RLK) that was identified by a genome-wide association study (GWAS) based on the natural variations in response to salinity stress [133]. MIK2 controls root growth direction under salt stress in a THE1-dependent manner [134]. The salthypersensitive phenotype of mik2 mutant can be suppressed by the1-1, a null mutation of THE1 [134]. Recently, the serine rich endogenous peptide (SCOOP) phytocytokines were identified as the ligands of MIK2 to trigger immune responses [135], but whether the SCOOP peptides participate in MIK2-mediated regulation of salt tolerance is still unknown. FEI1 and FEI2 are two LRR-RLKs that are associated with cellulose synthesis and anisotropic cell expansion and are involved in CWI sensing [136]. Double mutant fei1 fei2 displays root swelling and reduced cellulose biosynthesis under high sucrose or high salt conditions [137]. Genetic analysis indicated that FEI2 functions downstream of THE1 in mediating CWI perception [138]. Mid1-complementing activity 1 (MCA1) is a plasma membrane-localized stretch-activated $\mathrm{Ca}^{2+}$ channel and functions downstream of THE1 in Arabidopsis [95,139]. Like the1-1 mutant, mca1 seedlings exhibit reduced deposition of lignin and decreased jasmonic acid and salicylic acid biosynthesis in response to isoxaben-induced CWD [138].

Wall-associated kinases (WAKs) are a family of receptor-like Ser/Thr kinases whose extracellular domains are cross-linked with pectin fraction in a high affinity $[140,141]$. The EGF-like domain of WAK1/2 preferentially binds to de-methyl-esterified HG over methylesterified HG, and WAK1 also exhibits a high affinity with oligogalacturonides (OGs) in vitro $[140,142]$. The binding of WAKs to pectin and OGs occurs only in the presence of $\mathrm{Ca}^{2+}$ [140]. GRP-3, a glycine-rich cell wall protein, also acts as a potential switch for the kinase activity of WAK1 and negatively regulates the defense responses elicited by OGs [143]. A dominant allele of wak2 mutant exhibits constitutive activation of stress responses, including increased ROS accumulation and cell wall biogenesis [142,144]. Under long-term salt stress, tomato WAK1 mutant slwak1 exhibits disrupted osmotic homeostasis and elevated sucrose content in roots, which in turn negatively affects fruit yield [145]. Similarly, Ds transposon insertion mutant of HvWAK1 in barley displays decreased salt tolerance [146]. Although the WAKs have been shown to participate in the salt stress response, the existing experimental evidences to elaborate the roles of WAKs in sensing the CWI under salinity are still lacking. Recently, Gigli-Bisceglia et al. indicated that salinity stress-induced de-methyl-esterification of pectin activates stress signaling pathways, which may provide a direction to study the roles of WAKs in salt stress response [52] (Figure 1).

The CWD caused by salinity stress, isoxaben, an inhibitor of cellulose biosynthesis, or driselase, a cell wall-degrading enzyme, can increase the protein levels of hormone-like peptides PROPEP1/3, the precursors of plant elicitor peptide 1/3 (Pep1/3) $[138,147]$. The Pep3 knockdown plants and the null mutant of Pep1 receptor 1 (PEPR1) both exhibit salthypersensitivity [148]. These results suggest that the activation of PEPR1 by PROPEP3 positively regulates salt tolerance in Arabidopsis. Currently, the majority of studies on Peps-PEPRs complexes focus on their roles in plant immunity, and in future the roles of the Peps-PEPRs complexes-mediated signaling in abiotic stress responses need more investigations.

HPCA1 is a LRR-RLK required for the sense of extracellular $\mathrm{H}_{2} \mathrm{O}_{2}$ [128]. The two pairs of cysteine residues in the extracellular domain of HPCA1 are covalently modified by extracellular $\mathrm{H}_{2} \mathrm{O}_{2}$, which leads to the activation of HPCA1 and elevation of $\mathrm{Ca}^{2+}$ influx. In hpca1 mutant seedlings, the extracellular $\mathrm{H}_{2} \mathrm{O}_{2}$-induced $\mathrm{Ca}^{2+}$ influx, the activation of ABA signaling, and the phosphorylation of MPK3/6 are all inhibited [128]. It was shown that HPCA1 is not required for the salt stress-induced influx of $\mathrm{Ca}^{2+}$, but considering that 
high salinity can affect the redox status in the apoplast, so whether HPCA1 is also required for the sense of salt stress-induced redox changes worth further investigations.

\section{Salt Stress-Triggered Intracellular Signaling Pathway Regulated by Cell Wall Sensors}

Although several plasma membrane-localized cell wall integrity sensors have been identified that perceive cell wall changes, the intracellular signaling pathways that relay cell wall signals are still largely unknown. The phosphorylation of MPK6 is a marker of the environmental stimuli, and the transient activation of MPK6 under abiotic stress conditions, including high salinity and cold, has been reported [149]. As a major signaling transducer, the activity of MPK6 is regulated by multiple CWI sensors, such as FER, THE1, HERK1, and HPCA1 [52,128]. In future, the regulatory mechanisms of these CWI sensors on the activity of MPK6 need to be addressed.

After perception of CWD by cell wall sensors, plants can integrate and balance multiple hormone signals to improve salt tolerance. ABA and JA are the major hormones involved in the response to diverse environmental stresses. In the lrx 345 and fer-4 mutants, the ABA and JA contents are constitutively increased and the salt-hypersensitivity of these two mutants is largely caused by the disrupted homeostasis of phytohormones [150]. Phosphatase ABA insensitive 2 (ABI2) is a negative regulator of ABA signaling pathway, and FER activates the guanine nucleotide exchange factor (GEF) 1/4/10/Rho of plant 11 (ROP11) pathway to positively regulate the activity of ABI2 phosphatase, and thereby modulating ABA signaling pathway [151,152]. MYC2, a master transcription factor in JA signaling pathway, is also regulated by FER. FER positively regulates immunity by inhibiting JA signaling via the phosphorylation-mediated destabilization of MYC2 [153]. It has also been shown that MYC2 negatively regulates salt tolerance via the inhibition of proline biosynthesis [154]. In brief, these results suggest that FER controls the environmental stress responses via the modulation of the homeostasis of phytohormones (Figure 1).

\section{Cell Wall Repair under High Salinity}

Upon exposure to salt stress, the cortical microtubules in the hypocotyl of seedling are rapidly depolymerized, the process of which usually occurs within $2 \mathrm{~h}$ of salt application. However, at the growth recovery stage (after salt treatment for $\sim 8 \mathrm{~h}$ ), the cortical microtubules are reassembled into stable cortical arrays [16]. Evidences have shown that the rapid depolymerization of the cortical microtubules network is important for salt tolerance. For instance, stabilization of microtubules with paclitaxel leads to increased salt-hypersensitivity, whereas constitutive disruption of microtubules with oryzalin or propyzamide improves salt tolerance [155].

The depolymerization of cortical microtubules requires the alteration of the activities of the atypical microtubule-associated protein kinase propyzamide hypersensitive 1 (PHS1) and microtubule-associated protein SPIRAL1 (SPR1). Under normal growth conditions, the kinase activity of PHS1 is inhibited by its own phosphatase domain, while salt or osmotic stress blocks this inhibition and then enhances the phosphorylation and depolymerization of $\alpha$-tubulin [156]. SPR1 binds to the microtubules and antagonizes stress-induced cortical microtubule depolymerization. Under salt stress, SPR1 is rapidly degraded by the $26 \mathrm{~S}$ proteasome and the inhibition of microtubule depolymerization is relieved [157]. Histone H2B monoubiquitination (H2Bub1) participates in the regulation of the expression of protein tyrosine phosphatase 1 (PTP1) and MAP kinase phosphatase (MKP) genes, which in turn modulate the phosphorylation and dephosphorylation of microtubule-binding proteins via a PTP1/MKP-MPK3/6 signal mode, and finally promotes the rapid microtubule depolymerization under salt stress [158].

CSCs synthesize cellulose via the binding with cortical microtubules, and the polymerization status of cortical microtubules determines the movement of CSCs at the cell surface. CSCs are assembled in the Golgi apparatus and translocated to the plasma membrane via vesicle trafficking. Salt-induced depolymerization of microtubules is accompanied by the internalization of CSCs into small CesA compartments/microtubule-associated CesA 
compartments (smaCCs/MASCs) [15]. At the growth recovery stage after salt treatment, cortical microtubule is reassembled and CSCs is relocated to the plasma membrane to synthesize cellulose. Increasing evidences have shown that the efficiency of plants to reassembly cortical microtubule and cellulose during the growth recovery stage is critical for salt tolerance. CC1 and its paralog CC2 were identified as companions of CSCs and are required for the reassembly of cortical microtubule and subsequently cellulose biosynthesis during the growth recovery stage [16]. In $c c 1 c c 2$ double mutants, CSCs dissociate from the microtubules after salt treatment, but a stress-tolerant microtubule complex cannot be reproduced, resulting in the abolishment of the localization of CSCs at the plasma membrane and decreased cellulose synthesis. Microtubules-associated proteins 65-1 (MAP65-1) is a plant microtubule-bundling protein, which participates in the polymerization and bundling of cortical microtubules [159]. Phosphatidic acid (PA), a product of phospholipase D (PLD), binds to MAP65-1 and increases its activity to enhance microtubule polymerization and bundling [160]. The pld $\alpha 1$ mutant exhibits a defect in microtubule organization under salt stress and increased salt-hypersensitivity. Moreover, 16:0-18:2 PA can activate MPK6 via directly binding to MPK6 and the salt-induced transient activation of MPK6 is abolished in the pld $\alpha 1$ mutant [149].

Brassinosteroid insensitive 2 (BIN2), a master negative factor in brassinosteroid signal pathway, regulates the balance between salt stress response and growth recovery [161]. BIN2 is required for the negative regulation of cellulose biosynthesis. BIN2 phosphorylates CESA1 to inhibit the activity of CSCs [162]. By exploring turboID-mediated proximity labeling technology, Kim et al. found that BIN2 interacts with FER, but the biological significance of this interaction has not yet been resolved [163]. It is possible that FER regulates the activity of BIN2 via phosphorylation, and then modulates CesAs activity and cellulose biosynthesis under salt stress.

\section{Transcriptional Regulation of Cell Wall-Associated Genes under Salt Stress}

Under salinity stress, plant cells sense salt signals via receptors or sensors and then transmit the signals to the downstream regulatory networks to trigger the transcription of salt stress-responsive genes, which in turn promote the adjustment of the physiological, biochemical, and metabolic properties of plant cells to adapt to high salinity.

The transcriptional regulation of genes largely depends on the activity of the corresponding transcription factors. Some transcription factors have been identified that are required for the regulation of cell wall-associated genes in response to salt stress. For example, salt stress induces the accumulation of $\beta-1,4$-galactan in root cell walls through the up-regulation the of galactan synthase 1 (GALS1) gene. Based on a genetic screening, two transcription factors basic pentacysteine 1 (BPC1) and BPC2 were identified that directly bind to the promoter of the GALS1 gene and repress its expression [28]. The expression of $B P C 1$ and $B P C 2$ genes is significantly reduced under salt stress. The $b p c 1 b p c 2$ double mutant, in which the accumulation of $\beta-1,4$-galactan is elevated under salt stress compared with the wild type, exhibits increased salt tolerance [28]. Oryza sativa MULTIPASS (OsMPS) encodes an R2R3-type MYB transcription factor in rice. Expression profiling revealed that, upon $A B A$ or salt stress treatment, the expression of expansins, such as OsEXPA4, OsEXPA8, OsEXPB2, OsEXPB3, and OsEXPB6, and the expression of cell wall biosynthesis genes, such as endoglucanase genes OsGLU5 and OsGLU14, are negatively regulated by OsMPS [164]. XTH19 and XTH23, belonging to xyloglucan endotransglucosylase/hydrolase group II, are up-regulated by salt stress and BR [43]. In the $x$ th 23 single or $x$ th19 $x$ th 23 double mutant, lateral root growth is disrupted under salt stress, whereas overexpression of XTH19 or XTH23 enhances salt tolerance and increases lateral root initiation [43]. BRI1-EMS-SUPPRESSOR 1 (BES1) is a transcription factor that is involved in BR signaling pathway. BES1 directly binds the promoter of XTH19 and XTH23 and positively regulates their expression under salt stress [43] (Table 1).

Gene expression is also influenced by epigenetic regulation, such as histone modification and DNA methylation. Salt stress triggers the histone H3K9/K14 acetylation of 
some abiotic stress-responsive genes to crease their transcript levels [165]. General control nonderepressible 5 (GCN5), encoding a histone acetyltransferase, is induced by salt stress and acts as a maintainer of CWI. GCN5 mediates the acetylation of H3K9 and H3K14 in the promoters of CTL1, PGX3 (polygalacturonase involved in expansion-3), and MYB54 under salt stress, and thus fine-tunes their gene expression [32]. Constitutive expression of CTL1 partially restores the salt-hypersensitivity and CWD of the gcn5 mutant [32]. Similarly, the H3K9 acetylation level in the genome of maize is also elevated after salt treatment, and the increased acetylation level enhances the expression of ZmGCN5, which in turn promotes the expression of ZmEXPB2 and ZmXET1 genes [166].

\section{Conclusions and Future Perspective}

Cell wall is not just a mechanical support for plant cells, but is also the frontline to sense and transduce environmental stress signals. High salinity, as one of the globally distributed abiotic stresses, can disrupt the CWI, and the severity of the salt-triggered CWD largely depends on the concentration of the surrounding sodium ion combined with other environmental conditions, such as light intensity and water availability. Study of the mechanisms underlying the sensing and maintenance of CWI under salt stress not only strengthens our understanding of salt stress responses in plants but also provides new strategies for the cultivation of crops with improved salt tolerance. Regarding the associations between CWI and salt tolerance, there are still many questions remain to be addressed, and the most important ones could be that how the excessive accumulation of $\mathrm{Na}^{+}$in the apoplast affects the CWI, and how the salt-induced cell wall changes are sensed by the cell wall sensors. Moreover, the $\mathrm{Ca}^{2+}$ channels that are required for the relay of salttriggered cell wall stress signals need to be identified and the cell wall repair mechanisms under stress conditions need to be further investigated. With the development of gene editing technologies and improved transformation efficiency, editing of CWI-related genes in crops to generate salt-tolerant varieties can be applied in future.

Author Contributions: J.L., S.L. and W.Z. compiled the materials and wrote the first draft; J.L. and C.Z. edited and finalized the manuscript. All authors have read and agreed to the published version of the manuscript.

Funding: This work was supported by the National Natural Science Foundation of China (NSFC) (Grant No. 32070295), and the Shanghai Pujiang Program (Grant No. 20PJ1414800), and the Strategic Priority Research Program from the Chinese Academy of Sciences (Grant No. XDA27040104).

Data Availability Statement: Not applied in this study.

Conflicts of Interest: The authors declare no conflict of interest.

\section{References}

1. Munns, R.; Tester, M. Mechanisms of salinity tolerance. Annu. Rev. Plant Biol. 2008, 59, 651-681. [CrossRef] [PubMed]

2. Singh, A. Soil salinization management for sustainable development: A review. J. Environ. Manag. 2021, 277, 111383. [CrossRef]

3. Jesus, J.M.; Danko, A.S.; Fiúza, A.; Borges, M.T. Phytoremediation of salt-affected soils: A review of processes, applicability, and the impact of climate change. Environ. Sci. Pollut. Res. Int. 2015, 22, 6511-6525. [CrossRef] [PubMed]

4. Rengasamy, P. World salinization with emphasis on Australia. J. Exp. Bot. 2006, 57, 1017-1023. [CrossRef] [PubMed]

5. Van Zelm, E.; Zhang, Y.; Testerink, C. Salt tolerance mechanisms of plants. Annu. Rev. Plant Biol. 2020, 71, 403-433. [CrossRef] [PubMed]

6. Zhao, C.; Zhang, H.; Song, C.; Zhu, J.; Shabala, S. Mechanisms of plant responses and adaptation to soil salinity. Innovation 2020, 1, 100017. [CrossRef]

7. Caffall, K.H.; Mohnen, D. The structure, function, and biosynthesis of plant cell wall pectic polysaccharides. Carbohydr. Res. 2009, 344, 1879-1900. [CrossRef]

8. Voxeur, A.; Höfte, H. Cell wall integrity signaling in plants: "To grow or not to grow that's the question". Glycobiology 2016, 26, 950-960. [CrossRef]

9. Feng, W.; Kita, D.; Peaucelle, A.; Cartwright, H.N.; Doan, V.; Duan, Q.; Liu, M.C.; Maman, J.; Steinhorst, L.; Schmitz-Thom, I.; et al. The FERONIA receptor kinase maintains cell-wall integrity during salt stress through $\mathrm{Ca}^{2+}$ Signaling. Curr. Biol. 2018, 28, 666-675.e5. [CrossRef] 
10. Zhao, C.; Zayed, O.; Yu, Z.; Jiang, W.; Zhu, P.; Hsu, C.C.; Zhang, L.; Tao, W.A.; Lozano-Durán, R.; Zhu, J.K. Leucine-rich repeat extensin proteins regulate plant salt tolerance in Arabidopsis. Proc. Natl. Acad. Sci. USA 2018, 115, 13123-13128. [CrossRef] [PubMed]

11. Rui, Y.; Dinneny, J.R. A wall with integrity: Surveillance and maintenance of the plant cell wall under stress. New Phytol. 2020, 225, 1428-1439. [CrossRef] [PubMed]

12. Bacete, L.; Hamann, T. The role of mechanoperception in plant cell wall integrity maintenance. Plants 2020, 9, 574. [CrossRef] [PubMed]

13. Lampugnani, E.R.; Khan, G.A.; Somssich, M.; Persson, S. Building a plant cell wall at a glance. J. Cell Sci. 2018, 131. [CrossRef]

14. Somerville, C.; Bauer, S.; Brininstool, G.; Facette, M.; Hamann, T.; Milne, J.; Osborne, E.; Paredez, A.; Persson, S.; Raab, T.; et al. Toward a systems approach to understanding plant cell walls. Science 2004, 306, 2206-2211. [CrossRef]

15. Kesten, C.; Wallmann, A.; Schneider, R.; McFarlane, H.E.; Diehl, A.; Khan, G.A.; van Rossum, B.J.; Lampugnani, E.R.; Szymanski, W.G.; Cremer, N.; et al. The companion of cellulose synthase 1 confers salt tolerance through a Tau-like mechanism in plants. Nat. Commun. 2019, 10, 857. [CrossRef]

16. Endler, A.; Kesten, C.; Schneider, R.; Zhang, Y.; Ivakov, A.; Froehlich, A.; Funke, N.; Persson, S. A mechanism for sustained cellulose synthesis during salt stress. Cell 2015, 162, 1353-1364. [CrossRef] [PubMed]

17. Chun, H.J.; Baek, D.; Cho, H.M.; Lee, S.H.; Jin, B.J.; Yun, D.J.; Hong, Y.S.; Kim, M.C. Lignin biosynthesis genes play critical roles in the adaptation of Arabidopsis plants to high-salt stress. Plant Signal. Behav. 2019, 14, 1625697. [CrossRef] [PubMed]

18. McFarlane, H.E.; Döring, A.; Persson, S. The cell biology of cellulose synthesis. Annu. Rev. Plant Biol. 2014, 65, 69-94. [CrossRef]

19. Paredez, A.R.; Somerville, C.R.; Ehrhardt, D.W. Visualization of cellulose synthase demonstrates functional association with microtubules. Science 2006, 312, 1491-1495. [CrossRef] [PubMed]

20. Endler, A.; Persson, S. Cellulose synthases and synthesis in Arabidopsis. Mol. Plant 2011, 4, 199-211. [CrossRef] [PubMed]

21. Zhang, S.S.; Sun, L.; Dong, X.; Lu, S.J.; Tian, W.; Liu, J.X. Cellulose synthesis genes CESA6 and CSI1 are important for salt stress tolerance in Arabidopsis. J. Integr. Plant Biol. 2016, 58, 623-626. [CrossRef]

22. Kang, J.S.; Frank, J.; Kang, C.H.; Kajiura, H.; Vikram, M.; Ueda, A.; Kim, S.; Bahk, J.D.; Triplett, B.; Fujiyama, K.; et al. Salt tolerance of Arabidopsis thaliana requires maturation of $\mathrm{N}$-glycosylated proteins in the Golgi apparatus. Proc. Natl. Acad. Sci. USA 2008, 105, 5933-5938. [CrossRef] [PubMed]

23. Vain, T.; Crowell, E.F.; Timpano, H.; Biot, E.; Desprez, T.; Mansoori, N.; Trindade, L.M.; Pagant, S.; Robert, S.; Höfte, H.; et al. The cellulase KORRIGAN is part of the cellulose synthase complex. Plant Physiol. 2014, 165, 1521-1532. [CrossRef] [PubMed]

24. Kwon, Y.; Kim, S.H.; Jung, M.S.; Kim, M.S.; Oh, J.E.; Ju, H.W.; Kim, K.I.; Vierling, E.; Lee, H.; Hong, S.W. Arabidopsis hot2 encodes an endochitinase-like protein that is essential for tolerance to heat, salt and drought stresses. Plant J. 2007, 49, 184-193. [CrossRef] [PubMed]

25. Chen, Z.; Hong, X.; Zhang, H.; Wang, Y.; Li, X.; Zhu, J.K.; Gong, Z. Disruption of the cellulose synthase gene, AtCesA8/IRX1, enhances drought and osmotic stress tolerance in Arabidopsis. Plant J. 2005, 43, 273-283. [CrossRef]

26. Sánchez-Rodríguez, C.; Bauer, S.; Hématy, K.; Saxe, F.; Ibáñez, A.B.; Vodermaier, V.; Konlechner, C.; Sampathkumar, A.; Rüggeberg, M.; Aichinger, E.; et al. CHITINASE-LIKE1/POM-POM1 and its homolog CTL2 are glucan-interacting proteins important for cellulose biosynthesis in Arabidopsis. Plant Cell 2012, 24, 589-607. [CrossRef]

27. Zhao, C.; Zayed, O.; Zeng, F.; Liu, C.; Zhang, L.; Zhu, P.; Hsu, C.C.; Tuncil, Y.E.; Tao, W.A.; Carpita, N.C.; et al. Arabinose biosynthesis is critical for salt stress tolerance in Arabidopsis. New Phytol. 2019, 224, 274-290. [CrossRef]

28. Yan, J.; Liu, Y.; Yang, L.; He, H.; Huang, Y.; Fang, L.; Scheller, H.V.; Jiang, M.; Zhang, A. Cell wall $\beta-1,4$-galactan regulated by the BPC1/BPC2-GALS1 module aggravates salt sensitivity in Arabidopsis thaliana. Mol. Plant 2020, 14, 411-425. [CrossRef]

29. Laursen, T.; Stonebloom, S.H.; Pidatala, V.R.; Birdseye, D.S.; Clausen, M.H.; Mortimer, J.C.; Scheller, H.V. Bifunctional glycosyltransferases catalyze both extension and termination of pectic galactan oligosaccharides. Plant J. 2018, 94, 340-351. [CrossRef]

30. Yan, J.; Huang, Y.; He, H.; Han, T.; Di, P.; Sechet, J.; Fang, L.; Liang, Y.; Scheller, H.V.; Mortimer, J.C.; et al. Xyloglucan endotransglucosylase-hydrolase 30 negatively affects salt tolerance in Arabidopsis. J. Exp. Bot. 2019, 70, 5495-5506. [CrossRef]

31. Chen, J.; Chen, X.; Zhang, Q.; Zhang, Y.; Ou, X.; An, L.; Feng, H.; Zhao, Z. A cold-induced pectin methyl-esterase inhibitor gene contributes negatively to freezing tolerance but positively to salt tolerance in Arabidopsis. J. Plant Physiol. 2018, 222, 67-78. [CrossRef]

32. Zheng, M.; Liu, X.; Lin, J.; Liu, X.; Wang, Z.; Xin, M.; Yao, Y.; Peng, H.; Zhou, D.X.; Ni, Z.; et al. Histone acetyltransferase GCN5 contributes to cell wall integrity and salt stress tolerance by altering the expression of cellulose synthesis genes. Plant J. 2019, 97, 587-602.

33. Fang, C.; Li, K.; Wu, Y.; Wang, D.; Zhou, J.; Liu, X.; Li, Y.; Jin, C.; Liu, X.; Mur, L.; et al. OsTSD2-mediated cell wall modification affects ion homeostasis and salt tolerance. Plant Cell Environ. 2019, 42, 1503-1512. [CrossRef]

34. Liu, H.; Ma, Y.; Chen, N.; Guo, S.; Liu, H.; Guo, X.; Chong, K.; Xu, Y. Overexpression of stress-inducible OsBURP16, the $\beta$ subunit of polygalacturonase 1, decreases pectin content and cell adhesion and increases abiotic stress sensitivity in rice. Plant Cell Environ. 2014, 37, 1144-1158. [CrossRef]

35. Scheller, H.V.; Ulvskov, P. Hemicelluloses. Annu. Rev. Plant Biol. 2010, 61, 263-289. [CrossRef]

36. Zhang, B.; Gao, Y.; Zhang, L.; Zhou, Y. The plant cell wall: Biosynthesis, construction, and functions. J. Integr. Plant Biol. 2020, 63, 251-272. [CrossRef] 
37. Park, Y.B.; Cosgrove, D.J. Xyloglucan and its interactions with other components of the growing cell wall. Plant Cell Physiol. 2015, 56, 180-194. [CrossRef] [PubMed]

38. Hayashi, T.; Kaida, R. Functions of xyloglucan in plant cells. Mol. Plant 2011, 4, 17-24. [CrossRef] [PubMed]

39. Nishitani, K.; Tominaga, R. Endo-xyloglucan transferase, a novel class of glycosyltransferase that catalyzes transfer of a segment of xyloglucan molecule to another xyloglucan molecule. J. Biol. Chem. 1992, 267, 21058-21064. [CrossRef]

40. Choi, J.Y.; Seo, Y.S.; Kim, S.J.; Kim, W.T.; Shin, J.S. Constitutive expression of CaXTH3, a hot pepper xyloglucan endotransglucosylase/hydrolase, enhanced tolerance to salt and drought stresses without phenotypic defects in tomato plants (Solanum lycopersicum cv. Dotaerang). Plant Cell Rep. 2011, 30, 867-877. [CrossRef] [PubMed]

41. Cho, S.K.; Kim, J.E.; Park, J.A.; Eom, T.J.; Kim, W.T. Constitutive expression of abiotic stress-inducible hot pepper CaXTH3, which encodes a xyloglucan endotransglucosylase/hydrolase homolog, improves drought and salt tolerance in transgenic Arabidopsis plants. FEBS Lett. 2006, 580, 3136-3144. [CrossRef]

42. Han, Y.; Wang, W.; Sun, J.; Ding, M.; Zhao, R.; Deng, S.; Wang, F.; Hu, Y.; Wang, Y.; Lu, Y.; et al. Populus euphratica XTH overexpression enhances salinity tolerance by the development of leaf succulence in transgenic tobacco plants. J. Exp. Bot. 2013, 64, 4225-4238. [CrossRef]

43. Xu, P.; Fang, S.; Chen, H.; Cai, W. The brassinosteroid-responsive xyloglucan endotransglucosylase/hydrolase 19 (XTH19) and XTH23 genes are involved in lateral root development under salt stress in Arabidopsis. Plant J. 2020, 104, 59-75. [CrossRef]

44. Atmodjo, M.A.; Hao, Z.; Mohnen, D. Evolving views of pectin biosynthesis. Annu Rev. Plant Biol. 2013, 64, 747-779. [CrossRef]

45. Wolf, S.; Mouille, G.; Pelloux, J. Homogalacturonan methyl-esterification and plant development. Mol. Plant 2009, 2, 851-860. [CrossRef] [PubMed]

46. Fang, C.; Zhang, H.; Wan, J.; Wu, Y.; Li, K.; Jin, C.; Chen, W.; Wang, S.; Wang, W.; Zhang, H.; et al. Control of leaf senescence by an $\mathrm{MeOH}$-Jasmonates cascade that is epigenetically regulated by OsSRT1 in rice. Mol. Plant 2016, 9, 1366-1378. [CrossRef]

47. Lionetti, V.; Cervone, F.; Bellincampi, D. Methyl esterification of pectin plays a role during plant-pathogen interactions and affects plant resistance to diseases. J. Plant Physiol. 2012, 169, 1623-1630. [CrossRef] [PubMed]

48. Wormit, A.; Usadel, B. The multifaceted role of pectin methylesterase inhibitors (PMEIs). Int. J. Mol. Sci. 2018, 19, 2878. [CrossRef] [PubMed]

49. Wachsman, G.; Zhang, J.; Moreno-Risueno, M.A.; Anderson, C.T.; Benfey, P.N. Cell wall remodeling and vesicle trafficking mediate the root clock in Arabidopsis. Science 2020, 370, 819. [CrossRef]

50. Sénéchal, F.; Wattier, C.; Rustérucci, C.; Pelloux, J. Homogalacturonan-modifying enzymes: Structure, expression, and roles in plants. J. Exp. Bot. 2014, 65, 5125-5160. [CrossRef]

51. Lewis, K.C.; Selzer, T.; Shahar, C.; Udi, Y.; Tworowski, D.; Sagi, I. Inhibition of pectin methyl esterase activity by green tea catechins. Phytochemistry 2008, 69, 2586-2592. [CrossRef]

52. Gigli-Bisceglia, N.; Van Zelm, E.; Huo, W.; Lamers, J.; Testerink, C. Salinity stress-induced modification of pectin activates stress signaling pathways and requires HERK/THE and FER to attenuate the response. bioRxiv 2020. [CrossRef]

53. Yan, J.; He, H.; Fang, L.; Zhang, A. Pectin methylesterase 31 positively regulates salt stress tolerance in Arabidopsis. Biochem. Biophys. Res. Commun. 2018, 496, 497-501. [CrossRef]

54. Hocq, L.; Pelloux, J.; Lefebvre, V. Connecting homogalacturonan-type pectin remodeling to acid growth. Trends Plant Sci. 2017, 22, 20-29. [CrossRef]

55. Manunza, B.; Deiana, S.; Pintore, M.; Gessa, C. Interaction of $\mathrm{Ca}^{2+}$ and $\mathrm{Na}^{+}$ions with polygalacturonate chains: A molecular dynamics study. Glycoconj. J. 1998, 15, 297-300. [CrossRef] [PubMed]

56. Sechet, J.; Htwe, S.; Urbanowicz, B.; Agyeman, A.; Feng, W.; Ishikawa, T.; Colomes, M.; Kumar, K.S.; Kawai-Yamada, M.; Dinneny, J.R.; et al. Suppression of Arabidopsis GGLT1 affects growth by reducing the L-galactose content and borate cross-linking of rhamnogalacturonan-II. Plant J. 2018, 96, 1036-1050. [CrossRef]

57. O'Neill, M.A.; Eberhard, S.; Albersheim, P.; Darvill, A.G. Requirement of borate cross-linking of cell wall rhamnogalacturonan II for Arabidopsis growth. Science 2001, 294, 846-849. [CrossRef]

58. Vanholme, R.; De Meester, B.; Ralph, J.; Boerjan, W. Lignin biosynthesis and its integration into metabolism. Curr. Opin. Biotechnol. 2019, 56, 230-239. [CrossRef] [PubMed]

59. Barros, J.; Serrani-Yarce, J.C.; Chen, F.; Baxter, D.; Venables, B.J.; Dixon, R.A. Role of bifunctional ammonia-lyase in grass cell wall biosynthesis. Nat. Plants 2016, 2, 16050. [CrossRef] [PubMed]

60. Moura, J.C.; Bonine, C.A.; de Oliveira, F.V.J.; Dornelas, M.C.; Mazzafera, P. Abiotic and biotic stresses and changes in the lignin content and composition in plants. J. Integr. Plant Biol. 2010, 52, 360-376. [CrossRef]

61. Naseer, S.; Lee, Y.; Lapierre, C.; Franke, R.; Nawrath, C.; Geldner, N. Casparian strip diffusion barrier in Arabidopsis is made of a lignin polymer without suberin. Proc. Natl. Acad. Sci. USA 2012, 109, 10101-10106. [CrossRef]

62. Hilal, M.; Zenoff, A.M.; Ponessa, G.; Moreno, H.; Massa, E.M. Saline stress alters the temporal patterns of xylem differentiation and alternative oxidase expression in developing soybean roots. Plant Physiol. 1998, 117, 695-701. [CrossRef]

63. Jbir, N.; Chaïbi, W.; Ammar, S.; Jemmali, A.; Ayadi, A. Root growth and lignification of two wheat species differing in their sensitivity to $\mathrm{NaCl}$, in response to salt stress. C. R. Acad. Sci. III 2001, 324, 863-868. [CrossRef]

64. Sánchez-Aguayo, I.; Rodríguez-Galán, J.M.; García, R.; Torreblanca, J.; Pardo, J.M. Salt stress enhances xylem development and expression of $S$-adenosyl-L-methionine synthase in lignifying tissues of tomato plants. Planta 2004, 220, 278-285. [CrossRef] 
65. Hu, P.; Zhang, K.; Yang, C. BpNAC012 positively regulates abiotic stress responses and secondary wall biosynthesis. Plant Physiol. 2019, 179, 700-717. [CrossRef]

66. Guo, H.; Wang, Y.; Wang, L.; Hu, P.; Wang, Y.; Jia, Y.; Zhang, C.; Zhang, Y.; Zhang, Y.; Wang, C.; et al. Expression of the MYB transcription factor gene BplMYB46 affects abiotic stress tolerance and secondary cell wall deposition in Betula platyphylla. Plant Biotechnol. J. 2017, 15, 107-121. [CrossRef]

67. Duan, A.Q.; Tao, J.P.; Jia, L.L.; Tan, G.F.; Liu, J.X.; Li, T.; Chen, L.Z.; Su, X.J.; Feng, K.; Xu, Z.S.; et al. AgNAC1, a celery transcription factor, related to regulation on lignin biosynthesis and salt tolerance. Genomics 2020, 112, 5254-5264. [CrossRef] [PubMed]

68. Showalter, A.M. Structure and function of plant cell wall proteins. Plant Cell 1993, 5, 9. [PubMed]

69. Hervé, C.; Siméon, A.; Jam, M.; Cassin, A.; Johnson, K.L.; Salmeán, A.A.; Willats, W.G.; Doblin, M.S.; Bacic, A.; Kloareg, B. Arabinogalactan proteins have deep roots in eukaryotes: Identification of genes and epitopes in brown algae and their role in Fucus serratus embryo development. New Phytol. 2016, 209, 1428-1441. [CrossRef] [PubMed]

70. Sampedro, J.; Cosgrove, D.J. The expansin superfamily. Genome Biol. 2005, 6, 242. [CrossRef]

71. Ding, J.L.C.; Hsu, J.S.F.; Wang, M.M.C.; Tzen, J.T.C. Purification and glycosylation analysis of an acidic pectin methylesterase in jelly fig (Ficus awkeotsang) achenes. J. Agric. Food Chem. 2002, 50, 2920-2925. [CrossRef]

72. Castilleux, R.; Plancot, B.; Gügi, B.; Attard, A.; Loutelier-Bourhis, C.; Lefranc, B.; Nguema-Ona, E.; Arkoun, M.; Yvin, J.; Driouich, A.; et al. Extensin arabinosylation is involved in root response to elicitors and limits oomycete colonization. Ann. Bot. Lond. 2020, 125, 751-763. [CrossRef] [PubMed]

73. Ogawa-Ohnishi, M.; Matsushita, W.; Matsubayashi, Y. Identification of three hydroxyproline O-arabinosyltransferases in Arabidopsis thaliana. Nat. Chem. Biol. 2013, 9, 726-730. [CrossRef] [PubMed]

74. Egelund, J.; Obel, N.; Ulvskov, P.; Geshi, N.; Pauly, M.; Bacic, A.; Petersen, B.L. Molecular characterization of two Arabidopsis thaliana glycosyltransferase mutants, rra1 and $r$ ra2, which have a reduced residual arabinose content in a polymer tightly associated with the cellulosic wall residue. Plant Mol. Biol. 2007, 64, 439-451. [CrossRef] [PubMed]

75. Gille, S.; Hänsel, U.; Ziemann, M.; Pauly, M. Identification of plant cell wall mutants by means of a forward chemical genetic approach using hydrolases. Proc. Natl. Acad. Sci. USA 2009, 106, 14699. [CrossRef]

76. Velasquez, M.; Salter, J.S.; Dorosz, J.G.; Petersen, B.L.; Estevez, J.M. Recent advances on the posttranslational modifications of EXTs and their roles in plant cell walls. Front. Plant Sci. 2012, 3, 93. [CrossRef]

77. Draeger, C.; Ndinyanka, F.T.; Gineau, E.; Mouille, G.; Kuhn, B.M.; Moller, I.; Abdou, M.T.; Frey, B.; Pauly, M.; Bacic, A.; et al. Arabidopsis leucine-rich repeat extensin (LRX) proteins modify cell wall composition and influence plant growth. BMC Plant Biol. 2015, 15, 1-11. [CrossRef] [PubMed]

78. Ringli, C. The hydroxyproline-rich glycoprotein domain of the Arabidopsis LRX1 requires Tyr for function but not for insolubilization in the cell wall. Plant J. 2010, 63, 662-669. [CrossRef]

79. Shi, H.; Kim, Y.; Guo, Y.; Stevenson, B.; Zhu, J.K. The Arabidopsis SOS5 locus encodes a putative cell surface adhesion protein and is required for normal cell expansion. Plant Cell 2003, 15, 19-32. [CrossRef]

80. Basu, D.; Tian, L.; Debrosse, T.; Poirier, E.; Emch, K.; Herock, H.; Travers, A.; Showalter, A.M. Glycosylation of a fasciclin-like arabinogalactan-protein (SOS5) mediates root growth and seed mucilage adherence via a cell wall receptor-like kinase (FEI1/FEI2) pathway in Arabidopsis. PLoS ONE 2016, 11, e0145092. [CrossRef]

81. Tan, L.; Eberhard, S.; Pattathil, S.; Warder, C.; Glushka, J.; Yuan, C.; Hao, Z.; Zhu, X.; Avci, U.; Miller, J.S.; et al. An Arabidopsis cell wall proteoglycan consists of pectin and arabinoxylan covalently linked to an arabinogalactan protein. Plant Cell 2013, 25, 270-287. [CrossRef]

82. Hijazi, M.; Roujol, D.; Nguyen-Kim, H.; Del, R.C.C.L.; Saland, E.; Jamet, E.; Albenne, C. Arabinogalactan protein 31 (AGP31), a putative network-forming protein in Arabidopsis thaliana cell walls? Ann. Bot. 2014, 114, 1087-1097. [CrossRef]

83. Marowa, P.; Ding, A.; Kong, Y. Expansins: Roles in plant growth and potential applications in crop improvement. Plant Cell Rep. 2016, 35, 949-965. [CrossRef] [PubMed]

84. Cosgrove, D.J. Characterization of long-term extension of isolated cell walls from growing cucumber hypocotyls. Planta 1989, 177, 121-130. [CrossRef] [PubMed]

85. Wu, Y.; Cosgrove, D.J. Adaptation of roots to low water potentials by changes in cell wall extensibility and cell wall proteins. J. Exp. Bot. 2000, 51, 1543-1553. [CrossRef] [PubMed]

86. Geilfus, C.M.; Zörb, C.; Mühling, K.H. Salt stress differentially affects growth-mediating $\beta$-expansins in resistant and sensitive maize (Zea mays L.). Plant Physiol. Biochem. 2010, 48, 993-998. [CrossRef]

87. Xu, J.; Tian, J.; Belanger, F.C.; Huang, B. Identification and characterization of an expansin gene AsEXP1 associated with heat tolerance in C3 Agrostis grass species. J. Exp. Bot. 2007, 58, 3789-3796. [CrossRef]

88. Qiu, S.; Ma, N.; Che, S.; Wang, Y.; Peng, X.; Zhang, G.; Wang, G.; Huang, J. Repression of OsEXPA3 expression leads to root system growth suppression in rice. Crop. Sci. 2014, 54, 2201-2213. [CrossRef]

89. Geilfus, C.; Ober, D.; Eichacker, L.A.; Mühling, K.H.; Zörb, C. Down-regulation of ZmEXPB6 (Zea mays $\beta$-expansin 6) protein is correlated with salt-mediated growth reduction in the leaves of Z. mays L. J. Biol. Chem. 2015, 290, 11235-11245. [CrossRef]

90. Jadamba, C.; Kang, K.; Paek, N.; Lee, S.I.; Yoo, S. Overexpression of rice expansin 7 (Osexpa7) confers enhanced tolerance to salt stress in rice. Int. J. Mol. Sci. 2020, 21, 454. [CrossRef] 
91. Chen, Y.; Han, Y.; Kong, X.; Kang, H.; Ren, Y.; Wang, W. Ectopic expression of wheat expansin gene TaEXPA2 improved the salt tolerance of transgenic tobacco by regulating $\mathrm{Na}^{+} / \mathrm{K}^{+}$and antioxidant competence. Physiol. Plant. 2017, 159, 161-177. [CrossRef] [PubMed]

92. Han, Y.; Li, A.; Li, F.; Zhao, M.; Wang, W. Characterization of a wheat (Triticum aestivum L.) expansin gene, TaEXPB23, involved in the abiotic stress response and phytohormone regulation. Plant Physiol. Biochem. 2012, 54, 49-58. [CrossRef] [PubMed]

93. Miller, G.; Suzuki, N.; Ciftci-Yilmaz, S.; Mittler, R. Reactive oxygen species homeostasis and signalling during drought and salinity stresses. Plant Cell Environ. 2010, 33, 453-467. [CrossRef]

94. Raggi, S.; Ferrarini, A.; Delledonne, M.; Dunand, C.; Ranocha, P.; De Lorenzo, G.; Cervone, F.; Ferrari, S. The arabidopsis class III peroxidase AtPRX71 negatively regulates growth under physiological conditions and in response to cell wall damage. Plant Physiol. 2015, 169, 2513-2525. [CrossRef] [PubMed]

95. Denness, L.; McKenna, J.F.; Segonzac, C.; Wormit, A.; Madhou, P.; Bennett, M.; Mansfield, J.; Zipfel, C.; Hamann, T. Cell wall damage-induced lignin biosynthesis is regulated by a reactive oxygen species- and jasmonic acid-dependent process in Arabidopsis. Plant Physiol. 2011, 156, 1364-1374. [CrossRef]

96. Tenhaken, R. Cell wall remodeling under abiotic stress. Front. Plant Sci. 2015, 5, 771. [CrossRef] [PubMed]

97. Lee, Y.; Rubio, M.C.; Alassimone, J.; Geldner, N. A mechanism for localized lignin deposition in the endodermis. Cell 2013, 153, 402-412. [CrossRef]

98. Ozgur, R.; Turkan, I.; Uzilday, B.; Sekmen, A.H. Endoplasmic reticulum stress triggers ROS signalling, changes the redox state, and regulates the antioxidant defence of Arabidopsis thaliana. J. Exp. Bot. 2014, 65, 1377-1390. [CrossRef]

99. Torres, M.A.; Dangl, J.L. Functions of the respiratory burst oxidase in biotic interactions, abiotic stress and development. Curr. Opin. Plant Biol. 2005, 8, 397-403. [CrossRef]

100. Ma, L.; Zhang, H.; Sun, L.; Jiao, Y.; Zhang, G.; Miao, C.; Hao, F. NADPH oxidase AtrbohD and AtrbohF function in ROS-dependent regulation of $\mathrm{Na}_{+} / \mathrm{K}_{+}$homeostasis in Arabidopsis under salt stress. J. Exp. Bot. 2012, 63, 305-317. [CrossRef]

101. Ben, R.K.; Benzarti, M.; Debez, A.; Bailly, C.; Savouré, A.; Abdelly, C. NADPH oxidase-dependent $\mathrm{H}_{2} \mathrm{O}_{2}$ production is required for salt-induced antioxidant defense in Arabidopsis thaliana. J. Plant Physiol. 2015, 174, 5-15.

102. Smokvarska, M.; Francis, C.; Platre, M.P.; Fiche, J.B.; Alcon, C.; Dumont, X.; Nacry, P.; Bayle, V.; Nollmann, M.; Maurel, C.; et al. A plasma membrane nanodomain ensures signal specificity during osmotic signaling in plants. Curr. Biol. 2020, 30, 4654-4664.e4. [CrossRef] [PubMed]

103. Martinière, A.; Fiche, J.B.; Smokvarska, M.; Mari, S.; Alcon, C.; Dumont, X.; Hematy, K.; Jaillais, Y.; Nollmann, M.; Maurel, C. Osmotic stress activates two reactive oxygen species pathways with distinct effects on protein nanodomains and diffusion. Plant Physiol. 2019, 179, 1581-1593. [CrossRef]

104. Hao, H.; Fan, L.; Chen, T.; Li, R.; Li, X.; He, Q.; Botella, M.A.; Lin, J. Clathrin and membrane microdomains cooperatively regulate RbohD dynamics and activity in Arabidopsis. Plant Cell 2014, 26, 1729-1745. [CrossRef] [PubMed]

105. Passardi, F.; Penel, C.; Dunand, C. Performing the paradoxical: How plant peroxidases modify the cell wall. Trends Plant Sci. 2004, 9, 534-540. [CrossRef] [PubMed]

106. Schopfer, P. Hydroxyl radical-induced cell-wall loosening in vitro and in vivo: Implications for the control of elongation growth. Plant J. 2001, 28, 679-688. [CrossRef]

107. Jin, T.; Sun, Y.; Zhao, R.; Shan, Z.; Gai, J.; Li, Y. Overexpression of peroxidase gene GsPRX9 confers salt tolerance in soybean. Int. J. Mol. Sci. 2019, 20, 3745. [CrossRef]

108. Moussu, S.; Broyart, C.; Santos-Fernandez, G.; Augustin, S.; Wehrle, S.; Grossniklaus, U.; Santiago, J. Structural basis for recognition of RALF peptides by LRX proteins during pollen tube growth. Proc. Natl. Acad. Sci. USA 2020, 117, 7494-7503. [CrossRef]

109. Rayle, D.L.; Cleland, R. Enhancement of wall loosening and elongation by acid solutions. Plant Physiol. 1970, 46, 250-253. [CrossRef]

110. Hager, A. Role of the plasma membrane $\mathrm{H}^{+}$-ATPase in auxin-induced elongation growth: Historical and new aspects. J. Plant Res. 2003, 116, 483-505. [CrossRef]

111. Mangano, S.; Martínez, P.J.; Marino-Buslje, C.; Estevez, J.M. How does pH fit in with oscillating polar growth? Trends Plant Sci. 2018, 23, 479-489. [CrossRef]

112. Lindner, H.; Müller, L.M.; Boisson-Dernier, A.; Grossniklaus, U. CrRLK1L receptor-like kinases: Not just another brick in the wall. Curr. Opin. Plant Biol. 2012, 15, 659-669. [CrossRef]

113. Schallus, T.; Jaeckh, C.; Fehér, K.; Palma, A.S.; Liu, Y.; Simpson, J.C.; Mackeen, M.; Stier, G.; Gibson, T.J.; Feizi, T.; et al. Malectin: A novel carbohydrate-binding protein of the endoplasmic reticulum and a candidate player in the early steps of protein N-glycosylation. Mol. Biol. Cell 2008, 19, 3404-3414. [CrossRef]

114. Haruta, M.; Sabat, G.; Stecker, K.; Minkoff, B.B.; Sussman, M.R. A peptide hormone and its receptor protein kinase regulate plant cell expansion. Science 2014, 343, 408-411. [CrossRef] [PubMed]

115. Geilfus, C.M. The $\mathrm{pH}$ of the apoplast: Dynamic factor with functional impact under stress. Mol. Plant 2017, 10, 1371-1386. [CrossRef]

116. Bose, J.; Rodrigo-Moreno, A.; Lai, D.; Xie, Y.; Shen, W.; Shabala, S. Rapid regulation of the plasma membrane $\mathrm{H}_{+}-\mathrm{ATPase}$ activity is essential to salinity tolerance in two halophyte species, Atriplex lentiformis and Chenopodium quinoa. Ann. Bot. 2015, 115, 481-494. [CrossRef] [PubMed] 
117. Shi, H.; Quintero, F.J.; Pardo, J.M.; Zhu, J.K. The putative plasma membrane $\mathrm{Na}^{+} / \mathrm{H}^{+}$antiporter SOS1 controls long-distance Na ${ }^{+}$ transport in plants. Plant Cell 2002, 14, 465-477. [CrossRef] [PubMed]

118. Qiu, Q.; Barkla, B.J.; Vera-Estrella, R.; Zhu, J.; Schumaker, K.S. Na ${ }^{+} / \mathrm{H}^{+}$exchange activity in the plasma membrane of Arabidopsis. Plant Physiol. 2003, 132, 1041-1052. [CrossRef]

119. Moore, A.L.; Åkerman, K.E.O. Calcium and plant organelles. Plant Cell Environ. 1984, 7, 423-429. [CrossRef]

120. Liners, F.; Letesson, J.J.; Didembourg, C.; Van Cutsem, P. Monoclonal antibodies against pectin: Recognition of a conformation induced by calcium. Plant Physiol. 1989, 91, 1419-1424. [CrossRef]

121. Lopez-Hernandez, F.; Tryfona, T.; Rizza, A.; Yu, X.L.; Harris, M.O.B.; Webb, A.A.R.; Kotake, T.; Dupree, P. Calcium binding by arabinogalactan polysaccharides is important for normal plant development. Plant Cell 2020, 32, 3346. [CrossRef]

122. Choi, W.G.; Toyota, M.; Kim, S.H.; Hilleary, R.; Gilroy, S. Salt stress-induced $\mathrm{Ca}^{2+}$ waves are associated with rapid, long-distance root-to-shoot signaling in plants. Proc. Natl. Acad. Sci. USA 2014, 111, 6497-6502. [CrossRef]

123. Ogasawara, Y.; Kaya, H.; Hiraoka, G.; Yumoto, F.; Kimura, S.; Kadota, Y.; Hishinuma, H.; Senzaki, E.; Yamagoe, S.; Nagata, K.; et al. Synergistic activation of the Arabidopsis NADPH oxidase AtrbohD by Ca ${ }^{2+}$ and phosphorylation. J. Biol. Chem. 2008, 283, 88858892. [CrossRef] [PubMed]

124. Keller, T.; Damude, H.G.; Werner, D.; Doerner, P.; Dixon, R.A.; Lamb, C. A plant homolog of the neutrophil NADPH oxidase gp91 ${ }^{\text {phox }}$ subunit gene encodes a plasma membrane protein with $\mathrm{Ca}^{2+}$ binding motifs. Plant Cell 1998, 10, 255-266. [CrossRef]

125. Halfter, U.; Ishitani, M.; Zhu, J.K. The Arabidopsis SOS2 protein kinase physically interacts with and is activated by the calciumbinding protein SOS3. Proc. Natl. Acad. Sci. USA 2000, 97, 3735-3740. [CrossRef]

126. Liu, J.; Zhu, J.K. A calcium sensor homolog required for plant salt tolerance. Science 1998, 280, 1943-1945. [CrossRef]

127. Yuan, F.; Yang, H.; Xue, Y.; Kong, D.; Ye, R.; Li, C.; Zhang, J.; Theprungsirikul, L.; Shrift, T.; Krichilsky, B.; et al. OSCA1 mediates osmotic-stress-evoked $\mathrm{Ca}^{2+}$ increases vital for osmosensing in Arabidopsis. Nature 2014, 514, 367-371. [CrossRef] [PubMed]

128. Wu, F.; Chi, Y.; Jiang, Z.; Xu, Y.; Xie, L.; Huang, F.; Wan, D.; Ni, J.; Yuan, F.; Wu, X.; et al. Hydrogen peroxide sensor HPCA1 is an LRR receptor kinase in Arabidopsis. Nature 2020, 578, 577-581. [CrossRef] [PubMed]

129. Jiang, Z.; Zhou, X.; Tao, M.; Yuan, F.; Liu, L.; Wu, F.; Wu, X.; Xiang, Y.; Niu, Y.; Liu, F.; et al. Plant cell-surface GIPC sphingolipids sense salt to trigger $\mathrm{Ca}^{2+}$ influx. Nature 2019,572,341-346. [CrossRef]

130. Lin, W.; Tang, W.; Anderson, C.T.; Yang, Z. FERONIA's sensing of cell wall pectin activates ROP GTPase signaling in Arabidopsis. bioRxiv 2018, 269647.

131. Hématy, K.; Sado, P.E.; Van Tuinen, A.; Rochange, S.; Desnos, T.; Balzergue, S.; Pelletier, S.; Renou, J.P.; Höfte, H. A receptor-like kinase mediates the response of Arabidopsis cells to the inhibition of cellulose synthesis. Curr. Biol. 2007, 17, 922-931. [CrossRef]

132. Gonneau, M.; Desprez, T.; Martin, M.; Doblas, V.G.; Bacete, L.; Miart, F.; Sormani, R.; Hématy, K.; Renou, J.; Landrein, B.; et al. Receptor kinase THESEUS1 is a rapid alkalinization factor 34 receptor in Arabidopsis. Curr. Biol. 2018, 28, 2452-2458.e4. [CrossRef]

133. Julkowska, M.M.; Klei, K.; Fokkens, L.; Haring, M.A.; Schranz, M.E.; Testerink, C. Natural variation in rosette size under salt stress conditions corresponds to developmental differences between Arabidopsis accessions and allelic variation in the LRR-KISS gene. J. Exp. Bot. 2016, 67, 2127-2138. [CrossRef]

134. Van der Does, D.; Boutrot, F.; Engelsdorf, T.; Rhodes, J.; McKenna, J.F.; Vernhettes, S.; Koevoets, I.; Tintor, N.; Veerabagu, M.; Miedes, E.; et al. The Arabidopsis leucine-rich repeat receptor kinase MIK2/LRR-KISS connects cell wall integrity sensing, root growth and response to abiotic and biotic stresses. PLoS Genet. 2017, 13, e1006832. [CrossRef] [PubMed]

135. Rhodes, J.; Yang, H.; Moussu, S.; Boutrot, F.; Santiago, J.; Zipfel, C. Perception of a divergent family of phytocytokines by the Arabidopsis receptor kinase MIK2. Nat. Commun. 2021, 12, 705. [CrossRef]

136. Xu, S.L.; Rahman, A.; Baskin, T.I.; Kieber, J.J. Two leucine-rich repeat receptor kinases mediate signaling, linking cell wall biosynthesis and ACC synthase in Arabidopsis. Plant Cell 2008, 20, 3065-3079. [CrossRef] [PubMed]

137. Basu, D.; Wang, W.; Ma, S.; DeBrosse, T.; Poirier, E.; Emch, K.; Soukup, E.; Tian, L.; Showalter, A.M. Two hydroxyproline galactosyltransferases, GALT5 and GALT2, function in arabinogalactan-protein glycosylation, growth and development in Arabidopsis. PLoS ONE 2015, 10, e0125624. [CrossRef]

138. Engelsdorf, T.; Gigli-Bisceglia, N.; Veerabagu, M.; McKenna, J.F.; Vaahtera, L.; Augstein, F.; Van der Does, D.; Zipfel, C.; Hamann, T. The plant cell wall integrity maintenance and immune signaling systems cooperate to control stress responses in Arabidopsis thaliana. Sci. Signal. 2018, 11, eaao3070. [CrossRef] [PubMed]

139. Nakagawa, Y.; Katagiri, T.; Shinozaki, K.; Qi, Z.; Tatsumi, H.; Furuichi, T.; Kishigami, A.; Sokabe, M.; Kojima, I.; Sato, S.; et al. Arabidopsis plasma membrane protein crucial for $\mathrm{Ca}^{2+}$ influx and touch sensing in roots. Proc. Natl. Acad. Sci. USA 2007, 104, 3639-3644. [CrossRef] [PubMed]

140. Decreux, A.; Messiaen, J. Wall-associated kinase WAK1 interacts with cell wall pectins in a calcium-induced conformation. Plant Cell Physiol. 2005, 46, 268-278. [CrossRef] [PubMed]

141. He, Z.H.; Fujiki, M.; Kohorn, B.D. A cell wall-associated, receptor-like protein kinase. J. Biol. Chem. 1996, 271, 19789-19793. [CrossRef] [PubMed]

142. Kohorn, B.D.; Johansen, S.; Shishido, A.; Todorova, T.; Martinez, R.; Defeo, E.; Obregon, P. Pectin activation of MAP kinase and gene expression is WAK2 dependent. Plant J. 2009, 60, 974-982. [CrossRef] [PubMed]

143. Gramegna, G.; Modesti, V.; Savatin, D.V.; Sicilia, F.; Cervone, F.; De Lorenzo, G. GRP-3 and KAPP, encoding interactors of WAK1, negatively affect defense responses induced by oligogalacturonides and local response to wounding. J. Exp. Bot. 2016, 67, 1715-1729. [CrossRef] [PubMed] 
144. Kohorn, B.D.; Kohorn, S.L.; Todorova, T.; Baptiste, G.; Stansky, K.; McCullough, M. A dominant allele of Arabidopsis pectin-binding wall-associated kinase induces a stress response suppressed by MPK6 but not MPK3 mutations. Mol. Plant 2012, 5, 841-851. [CrossRef]

145. Meco, V.; Egea, I.; Ortíz-Atienza, A.; Drevensek, S.; Esch, E.; Yuste-Lisbona, F.J.; Barneche, F.; Vriezen, W.; Bolarin, M.C.; Lozano, R.; et al. The salt sensitivity induced by disruption of cell wall-associated kinase 1 (SIWAK1) tomato gene is linked to altered osmotic and metabolic homeostasis. Int. J. Mol. Sci. 2020, 21, 6308. [CrossRef] [PubMed]

146. Kaur, R.; Singh, K.; Singh, J. A root-specific wall-associated kinase gene, HvWAK1, regulates root growth and is highly divergent in barley and other cereals. Funct. Integr. Genom. 2013, 13, 167-177. [CrossRef]

147. Safaeizadeh, M.; Boller, T. Differential and tissue-specific activation pattern of the AtPROPEP and AtPEPR genes in response to biotic and abiotic stress in Arabidopsis thaliana. Plant Signal. Behav. 2019, 14, e1590094. [CrossRef] [PubMed]

148. Nakaminami, K.; Okamoto, M.; Higuchi-Takeuchi, M.; Yoshizumi, T.; Yamaguchi, Y.; Fukao, Y.; Shimizu, M.; Ohashi, C.; Tanaka, M.; Matsui, M.; et al. AtPep3 is a hormone-like peptide that plays a role in the salinity stress tolerance of plants. Proc. Natl. Acad. Sci. USA 2018, 115, 5810-5815. [CrossRef]

149. Yu, L.; Nie, J.; Cao, C.; Jin, Y.; Yan, M.; Wang, F.; Liu, J.; Xiao, Y.; Liang, Y.; Zhang, W. Phosphatidic acid mediates salt stress response by regulation of MPK6 in Arabidopsis thaliana. New Phytol. 2010, 188, 762-773. [CrossRef]

150. Zhao, C.; Jiang, W.; Zayed, O.; Liu, X.; Tang, K.; Nie, W.; Li, Y.; Xie, S.; Li, Y.; Long, T.; et al. The LRXs-RALFs-FER module controls plant growth and salt stress responses by modulating multiple plant hormones. Natl. Sci. Rev. 2020, 8, nwaa149. [CrossRef]

151. Chen, J.; Yu, F.; Liu, Y.; Du, C.; Li, X.; Zhu, S.; Wang, X.; Lan, W.; Rodriguez, P.L.; Liu, X.; et al. FERONIA interacts with ABI2-type phosphatases to facilitate signaling cross-talk between abscisic acid and RALF peptide in Arabidopsis. Proc. Natl. Acad. Sci. USA 2016, 113, E5519-E5527. [CrossRef] [PubMed]

152. Yu, F.; Qian, L.; Nibau, C.; Duan, Q.; Kita, D.; Levasseur, K.; Li, X.; Lu, C.; Li, H.; Hou, C.; et al. FERONIA receptor kinase pathway suppresses abscisic acid signaling in Arabidopsis by activating ABI2 phosphatase. Proc. Natl. Acad. Sci. USA 2012, 109, 14693-14698. [CrossRef] [PubMed]

153. Guo, H.; Nolan, T.M.; Song, G.; Liu, S.; Xie, Z.; Chen, J.; Schnable, P.S.; Walley, J.W.; Yin, Y. FERONIA receptor kinase contributes to plant immunity by suppressing jasmonic acid signaling in Arabidopsis thaliana. Curr. Biol. 2018, 28, 3316-3324.e6. [CrossRef] [PubMed]

154. Verma, D.; Jalmi, S.K.; Bhagat, P.K.; Verma, N.; Sinha, A.K. A bHLH transcription factor, MYC2, imparts salt intolerance by regulating proline biosynthesis in Arabidopsis. FEBS J. 2020, 287, 2560-2576. [CrossRef] [PubMed]

155. Wang, C.; Li, J.; Yuan, M. Salt tolerance requires cortical microtubule reorganization in Arabidopsis. Plant Cell Physiol. 2007, 48, 1534-1547. [CrossRef]

156. Fujita, S.; Pytela, J.; Hotta, T.; Kato, T.; Hamada, T.; Akamatsu, R.; Ishida, Y.; Kutsuna, N.; Hasezawa, S.; Nomura, Y.; et al. An atypical tubulin kinase mediates stress-induced microtubule depolymerization in Arabidopsis. Curr. Biol. 2013, 23, 1969-1978. [CrossRef]

157. Wang, S.; Kurepa, J.; Hashimoto, T.; Smalle, J.A. Salt stress-induced disassembly of Arabidopsis cortical microtubule arrays involves $26 \mathrm{~S}$ proteasome-dependent degradation of SPIRAL1. Plant Cell 2011, 23, 3412-3427. [CrossRef]

158. Zhou, S.; Chen, Q.; Sun, Y.; Li, Y. Histone H2B monoubiquitination regulates salt stress-induced microtubule depolymerization in Arabidopsis. Plant Cell Environ. 2017, 40, 1512-1530. [CrossRef] [PubMed]

159. Zhou, S.; Chen, Q.; Li, X.; Li, Y. MAP65-1 is required for the depolymerization and reorganization of cortical microtubules in the response to salt stress in Arabidopsis. Plant Sci. 2017, 264, 112-121. [CrossRef]

160. Zhang, Q.; Lin, F.; Mao, T.; Nie, J.; Yan, M.; Yuan, M.; Zhang, W. Phosphatidic acid regulates microtubule organization by interacting with MAP65-1 in response to salt stress in Arabidopsis. Plant Cell 2012, 24, 4555-4576. [CrossRef]

161. Li, J.; Zhou, H.; Zhang, Y.; Li, Z.; Yang, Y.; Guo, Y. The GSK3-like kinase BIN2 is a molecular switch between the salt stress response and growth recovery in Arabidopsis thaliana. Dev. Cell 2020, 55, 367-380.e6. [CrossRef] [PubMed]

162. Sánchez-Rodríguez, C.; Ketelaar, K.; Schneider, R.; Villalobos, J.A.; Somerville, C.R.; Persson, S.; Wallace, I.S. BRASSINOSTEROID INSENSITIVE2 negatively regulates cellulose synthesis in Arabidopsis by phosphorylating cellulose synthase 1. Proc. Natl. Acad. Sci. USA 2017, 114, 3533-3538. [CrossRef] [PubMed]

163. Kim, T.; Park, C.H.; Hsu, C.; Zhu, J.; Hsiao, Y.; Branon, T.; Xu, S.; Ting, A.Y.; Wang, Z. Application of TurboID-mediated proximity labeling for mapping a GSK3 kinase signaling network in Arabidopsis. bioRxiv 2019, 636324.

164. Schmidt, R.; Schippers, J.H.; Mieulet, D.; Obata, T.; Fernie, A.R.; Guiderdoni, E.; Mueller-Roeber, B. MULTIPASS, a rice R2R3-type MYB transcription factor, regulates adaptive growth by integrating multiple hormonal pathways. Plant J. 2013, 76, 258-273. [CrossRef]

165. Luo, M.; Wang, Y.; Liu, X.; Yang, S.; Lu, Q.; Cui, Y.; Wu, K. HD2C interacts with HDA6 and is involved in ABA and salt stress response in Arabidopsis. J. Exp. Bot. 2012, 63, 3297-3306. [CrossRef] [PubMed]

166. Hui, L.; Yan, S.; Zhao, L.; Tan, J.; Zhang, Q.; Gao, F.; Wang, P.; Hou, H.; Li, L. Histone acetylation associated up-regulation of the cell wall related genes is involved in salt stress induced maize root swelling. BMC Plant Biol. 2014, 14, 1-14. 